\title{
Bankacılık Sektöründe Bulanık Analitik Hiyerarşi Prosesi ve Bulanık TOPSIS Yöntemleri ile Finansal Performans Değerlendirmesi
}

\author{
Bahadır GÜLSÜN*1@, Kevser Neslihan ERDOĞMUŞ2 \\ 1,2 Yıldız Teknik Üniversitesi, Makine Fakültesi, Endüstri Mühendisliği Bölümü, 34349, İstanbul, Türkiye
}

(Alınış / Received: 30.10.2019, Kabul / Accepted: 30.10.2020, Online Yayınlanma / Published Online: 15.04.2021)

\author{
Anahtar Kelimeler \\ Banka finansal performans \\ değerlendirmesi, \\ Bulanik AHP, \\ Bulanık TOPSIS, \\ Performans değerlendirme
}

\begin{abstract}
Özet: Ülke ekonomisi üzerinde önemli etkiye sahip olan bankacllı sektöründe artan riskler, belirsizlikler ve rekabetler sebebi ile bankaların performans değerlendirme çalışmaları gün geçtikçe daha çok önem kazanmaktadır. Bu çalışmada bankaların finansal performanslarını etkileyen kriterler ele alınarak kriter açıklamalarına detaylı bir şekilde yer verilmiştir. İlgili kriterler bazında, 2013-2018 yılları için Türkiye Bankalar Birliği'nden alınan raporlara göre aktif büyüklük sıralamasında ilk sekiz bankanın Bulanık AHP ve Bulanık TOPSIS yöntemleri kullanılarak finansal performans değerlendirmesi yapılmaktadır. $\mathrm{Bu}$ çalışma kapsamında bir çalışma grubu oluşturulmuş olup, ilgili çalışma grubu tarafindan finansal performansı etkileyen kriterler ve bu kriterleri etkileyen alt kriterler birbirleri ile karşılaştırılarak analiz edilmiş ve kriter önem dereceleri Bulanık AHP yöntemi ile belirlenmiştir. Kriterlerin önem derecelerinin belirlenmesi sonrası belirli kriterler için ilgili çalışma grubuna anket çalışması uygulanmış ve anket sonuçları Bulanık TOPSIS ve Bulanık AHP yöntemleri değerlendirilerek banka performanslarının karşılaştırılması yapılmıştır.
\end{abstract}

\section{Financial Performance Evaluation by Fuzzy Analytic Hierarchy Process and Fuzzy TOPSIS In Banking Sector}

\section{Keywords}

Bank financial performance evaluation,

Fuzzy AHP,

Fuzzy TOPSIS,

Performance evaluation
Due to the increased risks, uncertainties and competition in the banking sector, which has a significant impact on the country's economy, the performance evaluation studies of banks has become increasingly important day by day. In this study, the criteria which is affecting on financial performance of the banks are discussed and the criteria explanations are given in detail. On the basis of relevant criteria, according to the report which is taken from "The Banks Association of Turkey" for 2013-2018, the financial performance of the first eight banks which are ranked in accordance with size of assets, evaluated using Fuzzy AHP and Fuzzy TOPSIS. Within the scope of this study, a study group was established and the criteria affecting financial performance and the sub-criteria affecting these criteria were analyzed and compared with each other and the criteria importance ratios were determined by the Fuzzy AHP method. After determining the importance ratings of the criteria, the questionnaire was conducted to the relevant study group for specific criteria and the banks' performances were compared by evaluating the survey results with the Fuzzy TOPSIS and Fuzzy AHP methods.

\section{Giriş}

Literatürde bankaların performansının değerlendirilmesinde çeşitli yöntemlerin kullanıldığı görülmektedir. $\mathrm{Bu}$ yöntemler arasında Analitik Hiyerarşi Prosesi (AHP - Analytic Hierarchy Process), Oran Analizi, Çok Kriterli Optimizasyon ve Uzlaşık Çözüm (VIKOR - Vise Kriterijumska Optimizacija I
Kompromisno Resenje), İdeal Çözme Dayalı Sıralama Tekniği (TOPSIS - Technique for Order Preference by Similarity to Ideal Solution), Gri İlişki Analizi (GİA Grey Incidence Analysis), Veri Zarflama Analizi (VZA) gibi yöntemlerin yanında AHP ile PROMETHEE (Preference Ranking Organisation Method for Enrichment Evaluations - Zenginleștirme Değerlendirmeleri için Tercih Sıralama Organizasyon 
Yöntemi), Bulanık AHP ile TOPSIS, Bulanık AHP ile VIKOR, Bulanı AHP ile SAW (Simple Additive Weighting - Basit Toplamlı Ağırlıklandırma) ve Bulanık AHP ile Bulanık Moora gibi yöntemlerin bir arada kullanıldığı çalışmalar bulunmaktadır.

Denizhan vd. [1] 2017 yılındaki çalışmalarında, yeşil tedarikçi seçimi ile klasik tedarikçi seçimi arasındaki farklılıklar ortaya konmaya çalışılmıştır. Yeşil tedarikçi seçim kriterleri belirlendikten sonra yeşil tedarikçi seçimi için AHP ve Bulanık AHP yöntemlerini kullanmıştır. Sonrasında ise klasik tedarikçi seçim kriterleri ile de seçim yapılmış olup çalışmanın sonunda yeşil kriterlerle yapılan tedarikçi seçimi ile klasik kriterler ile yapılan seçim sonuçları karşılaştırılmıştır.

Yacan [2] 2016 yılında yapmış olduğu çalışmasında, eğitim kalitesinin belirlenmesinde Bulanık AHP ve Bulanık TOPSIS yöntemlerinden faydalanmıştır. Bu çalışmada belirli üniversiteler ele alınmış ve bu üniversitelerde eğitim kalitesini karşılaștırabilmek için öncelikle eğitim kalitesini etkilediği düşünülen kriterler Bulanık AHP yöntemi ile karşılaştırılmış ve kriterler ağırlıklandırılmıştır. Bulanık TOPSIS yöntemi ile de üniversiteler arasından seçim yapılmış ve eğitim kalitesine göre üniversiteler sıralandırılmıştır.

Sağır ve Doğanalp [3] 2016 yılında yaptıkları çalışmalarında, Türkiye için enerji kaynaklarının karşılaştırılmasını ve seçimini Bulanık TOPSIS yöntemi ile yapmayı amaçlamıştır. $\mathrm{Bu}$ çalışmada yenilenebilir enerji, fosil enerji ve nükleer enerji olmak üzere üç çeşit enerji kaynağl değerlendirilmiştir. Enerji konusunda uzman kişiler karar verici grubunu oluşturmuş olup, on iki kriter üzerinden değerlendirme yapılmıştır. Bulanık TOPSIS ile yapılan çalışma sonucunda on iki kriter bazında değerlendirilerek, yenilenebilir enerji, fosil enerji ve nükleer enerjiden oluşan üç alternatif arasında sıralama yapılmıştır.

Çalışkan ve Eren [4] 2016 yılında yapmış oldukları çalışma ile bankaların performans değerlendirmesini çok kriterli karar verme yöntemleri ile değerlendirmiştir. Çalışmasında finansal rasyolar kullanarak AHP ve PROMETHEE yöntemleri ile bankaların performans analizi üzerine çalışma yapmiştır.

Şişman ve Doğan [5] 2016 yılındaki çalışmalarında, Borsa İstanbul'da hisse senetleri işlem gören on mevduat bankasının finansal performanslarını Bulanık AHP ve Bulanık MOORA yöntemleri ile ele almıştır. Bulanık AHP ile kriterler arasında ikili karşılaştırma yapılarak kriter ağırlıkları belirlenmiş sonrasında Bulanık MOORA yaklaşımı ile bankaların performans sıralaması ve değerlendirmesi yapılmıştır. Mandic vd. [6] 2014 yılındaki çalışmalarında, Sırbistan bankalarının finansal performanslarını Bulanı AHP ve TOPSIS yöntemlerini kullanarak değerlendirmiştir. $\mathrm{Bu}$ çalışmada Sırbistan'da yer alan 35 banka ele alınmış olup, performansını etkilediği düșünülen kriterler Bulanık AHP ile sıralanmış olup performans sıralaması için TOPSIS yöntemi uygulanmıştır.

Doğan [7] 2013 yılında yapmış olduğu çalışmasında, Chang tarafından 2006 yılında yapılan çalışmaya benzer olarak İMKB'de işlem görmüş on adet bankanın performans değerlendirmesini Gri İlişki Analizi yöntemini kullanarak incelemiştir.

$\mathrm{Bu}$ çalışma ile ele alınan bankaların performans değerlendirme sonuçları ile hangi bankaların en yüksek performansa sahip olduğu, hangilerinin performanslarını arttırmaya yönelik çalışma yapması gerektiği ve yapılacak performans artırım çalışmalarında öncelikli olarak hangi kriterler üzerine ağırlık verilmesi gerektiği konusunda yol göstermektedir. Ayrıca yatırımcılar için yatırım yapılacak bankanın belirlenmesi konusunda fayda sağlamaktadır.

\section{Materyal ve Metot}

Çok kriterli karar verme (CKKV) içerisinde birden çok disiplini barındırmaktadır. Bu disiplinler arasında yönetim, matematik, ekonomi ve sosyal bilimler gibi disiplinler yer almaktadır. Çok kriterli karar verme bu disiplinler aracılı̆̆ ile karar problemlerinin birden fazla boyutla değerlendirilebilmesini ve karar alınabilmesini sağlamaktadır. ÇKKV, yöneylem araştırmasının bir dalı olup son yıllarda hızla gelişerek diğer yöneylem araştırması dalları arasında en hızlı gelişen dalı olmayı başarmıştır.

ÇKKV sürecinde değerlendirilen tüm problemlerde bir veya birden fazla karar verici bulunur ve birden fazla kriter yer alır. Gerçek hayatta bir karar verme sırasında karar vermemizi etkileyen yüzlerce kriter olabilmektedir. ÇKKV sırasında karar vericiler kararlarını ya da seçimlerini etkileyecek en önemli kriterleri ele almaktadır.

\subsection{Analitik Hiyerarşi Süreci (AHP)}

Analitik Hiyerarşi Süreci (AHP) yöntemi 1970’li yıllarda Thomas L. Saaty tarafından geliştirilmiş olan bir yöntemdir. AHP yöntemi karmaşık yapılı olan çok kriterli karar verme problemlerinin çözümü için kullanılabilmektedir. Bu teknikte karar verici kişiler tarafindan problemde yer alan karar kriterlerinin önem dereceleri belirlenir. Karar verici kișiler kriterleri ve bu kriterlere bağlı alt kriterlerin önem derecelerini belirlerken Saaty'nin 1-9 ölçeği olarak isimlendirilen ölçek değerlerini kullanmaktadır. 1-9 ölçeği kullanılarak kriterlerin ikili karşılaştırmaları yapılır ve tüm kriterler değerlendirilerek karar alternatiflerine ait öncelik sıraları belirlenir [8]. 
Çok kriterli karar verme teknikleri arasında AHP'nin diğer tekniklerle karşılaştırıldığında kullanımının kolay olması ve objektif yargılar ile sübjektif yargıları da içeren karmaşık yapılı karar problemlerinde uygulanabilir olması sebebi ile diğer tekniklere göre daha fazla tercih edilebilmektedir.

AHP yönteminde karar problemine ait hiyerarşik yapı oluşturulurken her bir seviyedeki kriterlerin öncelik değerlerinin hesaplanabilmesi gerekmektedir. Kriterlerin öncelik değerlerinin hesaplanabilmesi için aynı seviyede yer alan elemanların ikili olarak karşılaştırılması gerekmektedir. AHP tekniğinin problem çözümlerinde uygulama adımları aşağıdaki gibi verilebilmektedir [9].

- Probleminin tanımlanması ve amacının belirlenmesi,

- Amacı gerçekleştirmek için ele alınması gereken karar kriterlerinin belirlenmesi ve listelenmesi,

- Karar alternatiflerinin belirlenmesi,

- Karar probleminde hiyerarşik yapının belirlenmesi,

- Hiyerarşik yapının her seviyesi için aynı seviyede bulunan kriterlerin ikili olarak karşılaştırılmasının yapılması ve öz değer, özvektörlerden yararlanarak kriterlerin önem derecelerinin belirlenmesi,

- Kriterlere göre alternatiflerin ikili karşılaştırılması ve öncelik değerlerinin hesaplanması,

- Uyum oranının hesaplanması,

- Göreceli öncelik değerlerine göre alternatiflerin sıralanmasının yapılması ve en yüksek öncelik değerine sahip olan alternatif seçiminin yapılması,

- Son adım olarak duyarlılık analizinin yapılmasıdır.

\subsection{Bulanık AHP Yöntemi}

Günlük hayatta birçok kez çeşitli belirsizlikler ile ya da kararsız kalınan durumlar ile karşılaşılır. Karar vericiler için nitel değerlerin yanında duygu ve düşünceler de verilecek karar üzerinde etkili olmaktadır. Bu gibi durumlarda ortaya belirsizlik durumları çlkmaktadır. Zadeh (1975)'in belirttiği gibi; günlük hayatımızda kesin değerlerden daha çok insan düşünce sistemini daha gerçekçi olarak yansıtabilen dilsel değişkenler ve dilsel terimler kullanılır. $\mathrm{Bu}$ nedenle insan düşünce sistemini tanımlayabilmek için kelimeler ve dilsel ifadelerden faydalanılmaktadır [10]. Çok kriterli karar verme tekniklerinden biri olan AHP yaklaşımında seçim yapılırken ya da karar verilirken bu gibi belirsizlik durumları ele alınmamaktadır. Birçok literatür araștırmasında da bu durumun AHP'nin önde gelen dezavantajlarından biri olduğu görülmektedir.

AHP yönteminde bulunan belirsizliği ortadan kaldırılması için Bulanık AHP yöntemi geliştirilmiştir.
Bulanık AHP yöntemi yapısında kesin değerler yerine belirli aralıklardaki değerler ile karar vermeye olanak sağlamaktadır. Bulanık AHP yöntemi bu yönü ile yöneticiler açısından da oldukça etkili bir yöntemdir [11].

\subsubsection{Genişletilmiş Analiz Yöntemi}

Bulanık AHP metotlarından biri olan Genişletilmiş Analiz Yönteminde de klasik AHP yöntemlerinde yapıldığı gibi kriterler birbirleri ile karşılaștırılır. Ancak Bulanık AHP'de yapılan karşılaştırmalarda üçgensel bulanık sayılar kullanılmaktadır.

Genişletilmiş Analiz Yönetimde ikili karşılaştırmalar yapılmaktadır. Bu karşılaştırmalarda kullanılan önem dereceleri ve sözel karşılıkları Tablo 1. de verilmiştir.

Tablo 1. Önem dereceleri ve sözel karşılıkları [12].

\begin{tabular}{cc}
\hline Üçgensel Bulanık Sayılar & Sözel Karşılıkları \\
\hline$(1,1,1)$ & Aynı \\
$(2 / 3,1,3 / 2)$ & Denk Önem \\
$(3 / 2,2,5 / 2)$ & Önemli \\
$(5 / 2,3,7 / 2)$ & Çok Önemli \\
$(7 / 2,4,9 / 2)$ & Kesin Önemli \\
\hline
\end{tabular}

Genişletilmiş Analiz Yönteminde üçgensel bulanık sayıların kullanımı ile kesin bir değer ile karar verilmesi yerine bulanık sayılar ile aslında belirli bir aralık değeri kullanılarak karar vermedeki belirsizliğin en iyi şekilde çözüme yansıtılması sağlanır.

Chang'in yöntemine göre, öncelikle ölçütler ve hedefler belirlenir. Hedefler arasından seçim yapılacakları, ölçütler ise bu hedefleri değerlendirirken dikkate alınacak kriterleri ifade etmektedir. Ölçütler ele alınarak hedeflerin her biri için mertebe analizi belirlenir. Böylece ölçüt sayısı kadar ( $m$ tane) mertebe analiz değeri ortaya çlkar. Mertebe analiz değerleri așağıdaki gibi ifade edilebilir.

$$
M_{g i}^{1}, M_{g i}^{2}, \ldots \ldots \ldots \ldots, M_{g i}^{m} \quad i=1,2, \ldots \ldots \ldots, n
$$

Üçgensel bulanık sayılar ise aşağıdaki gibi ifade edilebilir.

$$
M_{g i}^{j}(j=1,2, \ldots \ldots \ldots, n)
$$

Genişletilmiş Analiz Yönteminin uygulama adımlarından ilk adım olarak öncelikle her bir i nesnesi için i. nesnenin bulanık büyüklük değeri aşağıda verilen eşitlikteki gibi hesaplanmaktadır. $S_{i}$ değeri i. amacın sentez değerini ifade etmektedir.

$$
S_{i}=\sum_{j=1}^{m} M_{g i}^{j} *\left[\sum_{i=1}^{n} \sum_{j=1}^{m} M j g i\right]-1
$$


$\mathrm{S}_{\mathrm{i}}$ değeri hesaplaması sırasında kullanılan $\mathrm{M}$ jgi değeri, her bir amaca yönelik genişletilmiş değeri ifade etmektedir. (3) eşitliğinde yer alan $\sum_{\mathrm{j}=1}^{\mathrm{m}} \mathrm{M}_{\mathrm{gi}}^{\mathrm{j}}$ ifadesi (4) eşitliğindeki gibi hesaplanmaktadır. Bu hesaplama için 1'den $\mathrm{m}$ değerine kadar olan genişletilmiş analiz değeri bulanık toplama ișlemiyle toplanır ve bu işlem sonrasında bir matris elde edilir.

$$
\sum_{j=1}^{m} M_{g i}^{j}=\left(\sum_{j=1}^{m} l_{j} \sum_{j=1}^{m} m_{j} \sum_{j=1}^{m} u_{j}\right)
$$

(3) eşitliğinde yer alan [ $\left.\sum_{\mathrm{i}=1}^{\mathrm{n}} \sum_{\mathrm{j}=1}^{\mathrm{m}} \mathrm{Mjgi}\right]$-1 ifadesi ise (5) eşitliğindeki gibi hesaplanmaktadır. eşitliğinde yer alan $\sum_{i=1}^{n} u_{i}$ ifadesi tüm matrisin en geniş olası değerlerinin toplamını, $\sum_{\mathrm{i}=1}^{\mathrm{n}} \mathrm{m}_{\mathrm{i}}$ ifadesi ise tüm matrisin en olası değerlerinin toplamını ve $\sum_{i=1}^{n} l_{i}$ ifadesi ise tüm matrisin en az olası değerlerinin toplamını ifade etmektedir.

$$
\left[\sum_{i=1}^{n} \sum_{j=1}^{m} M_{g i}^{j}\right]^{-1}=\left[\frac{1}{\sum_{i=1}^{n} u_{i}}, \frac{1}{\sum_{i=1}^{n} m_{i}}, \frac{1}{\sum_{i=1}^{n} l_{i}}\right]
$$

Genişletilmiş Analiz Yönteminin ikinci adımı olarak; ilk adımda elde edilmiş olan sentez değerlerinin karşılaştırılması ve sonrasında kriterlere ait ağırlık değerlerinin elde edilmesi esasına dayanır. İkinci adım olarak bu karşılaştırmanın nasıl yapılması gerektiğine yer verilecektir. Karşılaştırılan kriterler $M_{2}$ ve $M_{1}$ olmak üzere eşitlik (6)'in olabilirlik derecesi aşağıdaki gibi tanımlanabilir.

$$
M_{2}=\left(l_{2}, m_{2}, u_{2}\right) \geq M_{1}=\left(l_{1}, m_{1}, u_{1}\right)
$$

$V\left(M_{2} \geq M_{1}\right)$ ifadesi $M_{2}$ 'nin $M_{1}$ 'den büyük olma olabilirliğini göstermektedir. $\mathrm{Bu}$ eșitlikte aşağıdaki denklemlerde detaylı verildiği gibi $\mathrm{M}_{2}$ 'nin orta değeri olan $\mathrm{m}_{2}$ değerinin, $\mathrm{M}_{1}{ }^{\prime}$ in orta değeri olan $\mathrm{m}_{1}{ }^{\prime}$ den büyük olma olabilirliği 1 değerini almaktadır. V $\left(M_{2} \geq M_{1}\right)$ değeri hesaplanırken $V\left(M_{2} \geq M_{1}\right)$ değerini de göz önünde bulundurmak gerekmektedir. $M_{2}$ ve $M_{1}, M_{2}=\left(l_{2}, m_{2}, u_{2}\right) \geq M_{1}=\left(l_{1}, m_{1}, u_{1}\right)$ olmak üzere;

$$
\begin{gathered}
V\left(M_{2} \geq M_{1}\right)=\sup _{y \geq x}\left[\left(\mu_{M_{1}}(x), \mu_{M_{2}}(y)\right)\right] \\
V\left(M_{2} \geq M_{1}\right)=\operatorname{hgt}\left(M_{1} \cap M_{2}\right)=\mu M_{2}(d) \\
V\left(M_{2} \geq M_{1}\right) \\
1 \\
\quad\left\{\begin{array}{cc}
0 & m_{2} \geq m_{1} \\
\frac{l_{1}-u_{2}}{\left(m_{2}-u_{2}\right)-\left(m_{1}-l_{1}\right)} & \text { diğer }
\end{array}\right.
\end{gathered}
$$

(8) ifadesinde geçen (d) $\mu_{M_{1}}$ ve $\mu_{M_{2}}$ değerleri aralığındaki en büyük kesişim noktası olan "D noktasının" ordinat değerini ifade etmektedir [13]. $M_{1}$ ve $M_{2}$ noktalarının kesişimi Şekil 1 . de gösterilmektedir.

Genişletilmiş Analiz Yönteminin üçüncü adımı olarak; M konveks bir bulanık sayı olmak üzere, M sayısının $\mathrm{k}$ konveks bulanık sayıdan $\mathrm{M}_{\mathrm{i}} \mathrm{i}=(1,2, \ldots \ldots \mathrm{k})$ daha büyük olması için olabilirlik derecesi (9) eşitliğindeki gibi ifade edilebilmektedir [14].

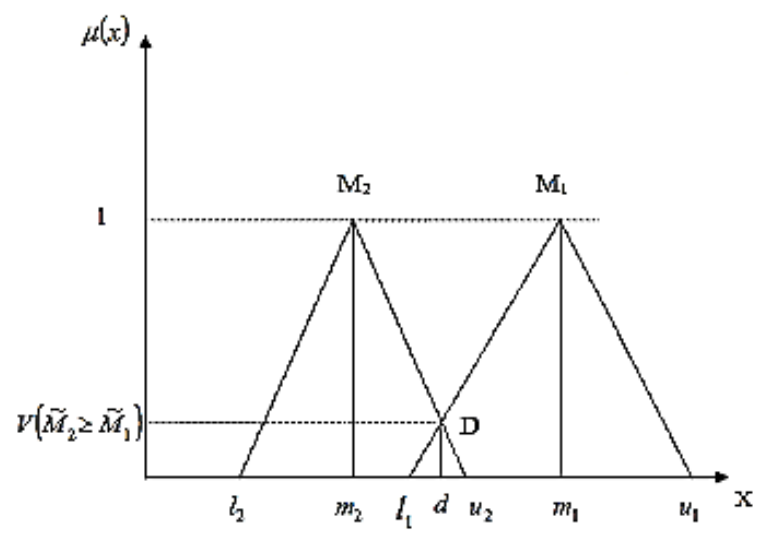

Şekil 1. $\mathbf{M}_{1}$ ve $\mathbf{M}_{2}$ noktalarının kesişimi [14].

$V\left(M \geq M_{1}, M_{2}, \ldots \ldots, M_{k}\right)=V\left[\left(M \geq M_{1}\right)\right.$ ve

$\left(M \geq M_{2}\right)$ ve , ... ve $\left.\left(M \geq M_{k}\right)\right]=$

$\operatorname{Min} V_{i}\left(M \geq M_{i}\right), i=(1,2, \ldots \ldots, k)$

$\mathrm{k}=1,2, \ldots, \ldots, \mathrm{n}$ için $\mathrm{k}^{1} \mathrm{i}$ olmak üzere ağırlık vektörü (11) eşitliğindeki gibi verilebilmektedir.

$$
W^{1}=\left(d^{1}\left(A_{1}\right), d^{1}\left(A_{2}\right), \ldots, \ldots, d^{1}\left(A_{n}\right)\right) T
$$

$A_{i}$, n elementli olmak üzere (12) eşitliğindeki gibi ifade edilebilmektedir.

$$
A_{i}=(i=1,2, \ldots \ldots, n)
$$

Genișletilmiș Analiz Yönteminin dördüncü adımı olarak; W Ağırlık vektörü bulunduktan sonra bu değeri normalize etmek için normalizasyon işlemi yapılır. (13) eşitliği sonuncunda artık bulunan ağırlık vektörü bulanık olmayan bir sayıdır.

$$
W=\left(d\left(A_{1}\right), d\left(A_{2}\right), \ldots, \ldots, d\left(A_{n}\right)\right) T
$$

AHP yönteminden farklı olarak Bulanık AHP yönteminde tutarlılık değerinin yapılan literatür araştırmalarında yapılmadığı görülmüştür. Bunun sebebi ise Bulanık AHP de kriter ağırlıkları sıfır çıkabilmesidir. Tutarlılık değeri hesaplanırken ikili karşılaștırma matrisi ile ağırlık vektörü ile çarpılması gerekmektedir. Sonrasında ise ağırlık vektörünün her bir elemanına bölünmesi ile ișleme devam edilir. Ağırlık vektörünün elemanlarından herhangi biri ya da daha fazlası sıfır olabilir. $\mathrm{Bu}$ gibi durumda sayıların sıfıra bölünmesi söz konusu olması sebebi ile matematikte tanımsızlık olarak ifade edilen durum ile karşılaşılabilmektedir [15].

\subsection{TOPSIS Yöntemi}

TOPSIS yöntemi çok kriterli karar verme tekniklerinden biri olarak kullanılmaktadır. TOPSIS, 
1981 yılında Hwang ve Yoon tarafından geliștirilmiștir [16].

TOPSIS yöntemi diğer karar verme tekniklerine göre kompleks algoritmalar ya da karmaşık matematiksel modeller içermemesinden dolayı oldukça kolay bir karar verme tekniğidir. TOPSIS yöntemi uygulanırken ele alınan alternatiflerin ideal çözüme yakın olması istenir. Bunun yanında ideal olmayan çözüme ise uzak olması istenen durumdur. TOPSIS yöntemi ile alternatifler arasından ideal çözüme yakın olan ve negatif ideal çözüme ise en uzak olan seçilmeye çalışılır.

TOPSIS yöntemi uygulanırken öncelikle karar matrisi olușturulur. Daha sonra elde edilen bu karar matrisi normalize edilir. Normalize edilen matris ağırlıklandırılır ve ideal çözüme en yakın ve en uzak olan mesafeler hesaplanır. Son aşama olarak da alternatifler için elde edilen göreceli puanlar hesaplanır ve elde edilen puanlara göre alternatifler siralanır [17].

TOPSIS yönteminin ilk adımında karar matrisi olușturularak alternatifler ve kriterler belirlenir. Karar matrisi $a \times b$ boyutlu bir matris olacaktır.

İkinci adım olarak; matriste yer alan kriterlere ait puanların kareleri toplanır ve bu toplamın karekökü alınır. İlgili eşitlik (14)'tek gibi ifade edilebilmektedir. Böylelikle matris normalize edilmiş olur.

$n_{i j}=\frac{a_{i j}}{\sqrt{\sum_{i=1}^{m} a_{i j}^{2}}}(i=1, \ldots \ldots, m$ ve $j=1, \ldots \ldots, p)$

Üçüncü adım olarak; ikinci adımda normalize edilmiş olan matris elemanları her bir kriter için verilmiș olan önem derecesine göre karar vericinin görüşleri doğrultusunda ağırlıklandırılır. Ağırlıklandırma ișleminde tüm kriter ağırlıklarının toplamının 1'e eșit olmasına dikkat edilmesi gerekmektedir. İkinci adımda elde edilen $\mathrm{n}_{\mathrm{ij}}$ değerleri, bu adımda $\mathrm{W}_{\mathrm{i}}$ olarak ifade edilen ağırlıklar ile çarpılır. Bunun sonucunda ağırlıklandırılmış ve normalize edilmiş matris elde edilir.

Yöntemin dördüncü adımında ideal ve negatif ideal çözüm değerlerinin elde edilmesidir. Bu aşamada matriste yer alan değerlerden her bir kolonda için en büyük ve en küçük değerler bulunur. Eğer problemdeki amaç maksimizasyon ise bu durumda her kolondaki en büyük değerler alınır ve maksimum ideal çözüm değeri bulunmuş olur. Her bir kolon için en küçük değerler alınarak da negatif ideal çözüm değerleri alınmış olur. Eğer bir minimizasyon problemi ele alıyor ise bu durumda yapılacak işlem tam tersi olur.

Her bir sütundaki maksimum değerler eșitlik (15)'teki gibi ifade edilmektedir.

$$
A^{*}=\left\{V_{1}^{*}, V_{2}^{*}, \ldots, V_{N}^{*}\right\}
$$

Her bir sütundaki minimum değerler eşitlik (16)'daki gibi ifade edilmektedir.

$$
A^{-}=\left\{V_{1}^{-}, V_{2}^{-}, \ldots, V_{N}^{-}\right\}
$$

Yöntemin beșinci aşamasında ise ideal olan ve de ideal olmayan noktalara olan uzaklık değerleri hesaplanmaktadır. (17) eșitliğindeki bu hesaplama için öklidyen uzaklıklar kullanılır.

$$
d_{i j}=\sqrt{\sum_{k=1}^{p}\left(x_{i k}-x_{j k}\right)}
$$

$\mathrm{x}_{\mathrm{ik}}$, i. gözlemin k. Değişken değerini ifade etmek olup, $\mathrm{x}_{\mathrm{jk}}, \mathrm{j}$. gözlemin k. değişken değerini ifade etmektedir. p değeri ise değişken sayısını göstermektedir.

(17) eşitliğini genelleştirecek olursak ideal ve negatif ideal uzaklık hesaplamaları için (18) ve (19) eşitlikleri verilebilmektedir. İdeal uzaklık değeri (18) eşitliğindeki gibi ifade edilebilmektedir.

$$
S_{i}^{*}=\sqrt{\sum_{j=1}^{n}\left(V_{i j}-V_{j}^{*}\right)^{2}}
$$

Negatif uzaklık değeri ise (19) eşitliğindeki gibi ifade edilebilmektedir.

$$
S_{i}^{-}=\sqrt{\sum_{j=1}^{n}\left(V_{i j}-V_{j}^{-}\right)^{2}}
$$

Problem çözümünde bulunacak $\mathrm{S}_{\mathrm{i}}^{*}$ ve $\mathrm{S}_{\mathrm{i}}^{-}$sayısı karar noktası sayısına eşit olacaktır.

Son aşama olan altıncı aşamada ise ideal çözüme göreli yakınlığın hesaplanmasıdır. İdeal çözüme yakınlık için ideal ve ideal olmayan noktalara olan uzaklıklar kullanılır. Formülasyonlarda $\mathrm{C}_{\mathrm{i}}^{*}$ değeri ideal çözüme olan yakınlı̆̆ı ifade etmektedir. $\mathrm{C}_{\mathrm{i}}^{*}$ ifadesi (20) eșitliğindeki gibi hesaplanabilmektedir.

$$
C_{i}^{*}=\frac{S_{i}^{-}}{S_{i}^{-}+S_{i}^{*}}
$$

\subsubsection{Bulanık TOPSIS Yöntemi}

İnsan yargılarının belirsiz olması ve kesin değerler ile ifade edilememesi doğru modellemelerin ve doğru seçimlerin yapılabilmesini engellemektedir. $\mathrm{Bu}$ sebeple TOPSIS yöntemi ile bulanık mantık yaklaşımları bir araya getirilerek Bulanık TOPSIS yöntemi ortaya çıkarılmıştır. Bulanık TOPSIS yöntemi 
ile problemlere daha gerçekçi bir çözüm sunabilmek adına sayısal değerler yerine sözel ifadeler kullanılarak insan yargılarının da daha doğru bir șekilde modele yansıtılabilmesi sağlanmıștır. Bulanık TOPSIS yönteminde düşük, çok düşük, yüksek gibi sözel ifadeler ile problemde yer alan karar kriterlerinin ve ağırlıklarının değerlendirilmesi yapılır.

Bulanık TOPSIS yönteminde öncelikle arasından seçim yapılacak alternatiflerin, bu alternatiflerin değerlendirileceği karar kriterlerinin ve de seçimi yapacak olan karar vericilerin belirlenmesi gerekir. Seçim yapacak olan karar verici grup alternatifleri ve karar kriterlerini değerlendirir.

Bulanık TOPSIS yöntemi ile özellikle sözel belirsizliklerin olduğu, karar vericilerin kararlarının birbirinden farklılık ya da değişkenlik göstermesi gibi durumlarda kullanılması ile grup kararının daha doğru bir șekilde verilmesine olanak sağlar. Karar vericilerin alternatifleri değerlendirmek için kullandıkları karar kriterlerinin farklı ağırlıklara sahip olması Bulanık TOPSIS yönteminin esaslarındandır [18].

Bulanık TOPSIS yönteminde alternatiflerin değerlendirilmesi ve de kriterlerin ağırlıklandırılması sırasında faydalanılan dilsel ifadelerin üçgensel bulanık sayı karşılıkları Tablo 2. ve Tablo 3. de verilmektedir.

Tablo 2. Karar kriterleri sözel ifadeler ve üçgensel bulanık sayı karșılıkları [19].

\begin{tabular}{cc}
\hline Sözel İfadeler & Bulanık Sayı Karşılıkları \\
\hline Çok İyi (Ç̇̇) & $(9 ; 10 ; 10)$ \\
İyi (İ) & $(7 ; 9 ; 10)$ \\
Orta İyi (Oİ) & $(5 ; 7 ; 9)$ \\
Orta (O) & $(3 ; 5 ; 7)$ \\
Orta Kötü (OK) & $(1 ; 3 ; 5)$ \\
Kötü (K) & $(0 ; 1 ; 3)$ \\
Çok Kötü (ÇK) & $(0 ; 0 ; 1)$ \\
\hline
\end{tabular}

Tablo 3. Alternatiflerin için sözel ifadeler ve üçgensel bulanık sayı karşılıkları [19].

\begin{tabular}{cc}
\hline Sözel İfadeler & Bulanık Sayı Karşılıkları \\
\hline Çok Yüksek (ÇY) & $(0,9 ; 1 ; 1)$ \\
Yüksek (Y) & $(0,7 ; 0,9 ; 1)$ \\
Orta Yüksek (OY) & $(0,5 ; 0,7 ; 0,9)$ \\
Orta (O) & $(0,3 ; 0,5 ; 0,7)$ \\
Orta Düșük (OD) & $(0,1 ; 0,3 ; 0,5)$ \\
Düşük (D) & $(0 ; 0,1 ; 0,3)$ \\
Çok Düşük (ÇD) & $(0 ; 0 ; 0,1)$ \\
\hline
\end{tabular}

Chen tarafından 2000 yllında geliștirilen Bulanık TOPSIS yöntemine (Tepe noktası yaklaşımı) ait uygulama adımları aşağıda verilmektedir [20]. İlk adım olarak $\mathrm{m}$ tane alternatif, $\mathrm{n}$ tane seçim kriterine karşılık değerlendirmesi yapılır. Alternatifler ve seçim kriterleri (21) ve (22) eşitliklerindeki gibi ifade edilebilmektedir.

$$
\begin{gathered}
A_{i}=(1,2,3, \ldots \ldots, m) \\
C_{j}=(1,2,3, \ldots \ldots)
\end{gathered}
$$

Karar vericiler tarafından kullanılan dilsel değișkenler aracılı̆̆g ile ağırlık vektörü ve karar matrisi oluşturulur. Ağırlık vektörü eşitlik (23)'teki gibi ifade edilebilmektedir.

$$
W=\left(w_{1}, w_{2}, \ldots w_{n}\right)
$$

Karar matrisi ise (24) ve (25) eşitliğindeki gibi ifade edilebilmektedir.

$$
\begin{gathered}
X=\left\{\begin{array}{c}
x_{i j}, i=1,2, \ldots, m ; \\
j=1,2, \ldots, n
\end{array}\right\} \\
X=\begin{array}{llllll}
A_{1} & C_{2} & \ldots & C_{n} \\
\hline A_{1} & x_{11} & x_{12} & \ldots & x_{1 n} \\
A_{i} & X_{21} & X_{22} & \ldots & X_{2 n} \\
\ldots & \ldots & \ldots & \ldots & \ldots \\
A_{n} & x_{m 1} & x_{m 2} & \ldots & x_{m n}
\end{array}
\end{gathered}
$$

W ağırlık vektörü, seçim kriterlerinin göreceli önemini eşitlik (26)'da ifade edilmektedir.

$$
C_{j}=(1,2,3, \ldots)
$$

(23) eşitliği, karar matrisi seçim kriteri olan $C_{j}$ bakımından $A_{i}$ alternatifinin fayda derecesinin göstermektedir. Verilen ağırlık vektörü ve karar matrisi aracılığ 1 ile problemin hedeflenen sonucuna paralel olarak tüm alternatiflerin sıralaması elde edilmiş olur.

Modelde yer alan kriterler için her bir kritere bağlı alt kriterleri bakımından ağırlıkları hesaplanır. Kriterlerin değerlendirilmesi sırasında üçgensel sayıların kullanılması sebebi ile hesaplanan ağırlıklarda üçgensel sayı olarak ortaya çıkmaktadır.

Her bir kriterin alternatiflere göre değerlendirilmesi sonucu karar matrisi ortaya çıkarılmaktadır. Karar matrisinde her bir kriter tüm alternatifler için değerlendirilmesi sırasında kritere bağlı alt kriterler açısından değerlendirilir.

Yöntemin ikinci adımı olarak; kriterlerin alternatiflere göre değerlendirilmesi sonucunda toplam ağırlıklar bulunur ve bulunan bu ağırlıklar $[0,1]$ aralı̆̆ına indirgenmesi için normalizasyon işlemi yapılmaktadır. Normalize edilmiş bir karar matris (27) eşitliğindeki gibi ifade edilebilir. Normalizasyon ișlemleri sırasında değerlendirilen kriterler fayda ve maliyet kriterleri olarak ikiye ayrilabilir. Değerlendirilen kriterin gelir ya da fayda kriteri olduğuna ya da tam tersi gider ya da zarar 
kriteri olmasına göre aşağıdaki işlemler yapılmaktadır. $r_{i j}$ değerleri hesaplanırken $B$ fayda kriterini, C ise maliyet kriterini göstermektedir. $r_{i j}$ değerleri fayda kriteri olarak eşitlik (28)'deki gibi hesaplanırken, zarar kriteri olarak ise (29) eşitliğindeki gibi hesaplanmaktadır. Normalizasyon işlemi yapılırken karar kriterinin fayda kriteri olması durumunda matristeki her sütundaki elemanların üçüncü bileșenine bakılır. Üçüncü bileșeni bazında en büyük olan değere bölünmesi ile normalizasyon işlemi yapılmış olur. Karar kriterinin maliyet kriteri olması durumunda ise her sütunda yer alan elemanların ilk bileşeni dikkate alınır. $u_{j}^{+}$değeri (30) eşitliğindeki gibi ifade edilebilmektedir. $u_{j}^{-}$değeri ise eşitlik (31)'de ifade edilmiştir.

$$
\begin{aligned}
& \begin{array}{c|llll}
\multicolumn{1}{c}{} & \multicolumn{1}{c}{C_{1}} & C_{J} & \ldots & C_{n} \\
\cline { 2 - 6 } A_{11} & r_{1 j} & \ldots & r_{1 n} \\
A_{i} & r_{21} & r_{i j} & \ldots & r_{i n} \\
\ldots & \ldots & \ldots & \ldots & \ldots \\
A_{m} & r_{m 1} & r_{m j} & \ldots & r_{m n}
\end{array} \\
& r_{i j}=\frac{x_{i, j}}{u_{j}^{+}}=\left(\frac{l_{x i j}}{u_{j}^{+}} ; \frac{m_{x i j}}{u_{j}^{+}} ; \frac{u_{x i j}}{u_{j}^{+}}\right) j \in B \\
& r_{i j}=\frac{l_{j}^{-}}{u_{i, j}}=\left(\frac{l_{j}^{-}}{u_{i j}^{+}} ; \frac{l_{j}^{-}}{u_{i j}^{+}} ; \frac{l_{j}^{-}}{u_{i j}^{+}}\right) j \in C \\
& u_{j}^{+}=\max \left(u_{i, j}\right) \forall i=1,2, \ldots, m \in B \\
& u_{j}^{-}=\min \left(l_{i, j}\right) \forall i=1,2, \ldots, m \in C
\end{aligned}
$$

Yöntemin üçüncü adımda ağırlıklı normalizasyon değerleri elde edilir. İkinci adımda normalize edilmiş karar matrisi olușturulduktan sonra her bir karar kriterinin birbirinden farklı önem derecesine sahip olabileceği dikkate alınarak, normalizasyon sonucu ortaya çıkan değerler ile kriter ağırlıkları çarpılır ve böylece ağırlıklandırılmış normalize karar matris (32) eşitliğindeki gibi elde edilir. $V_{i, j}$ ve $\forall i$ değerlerine ilişkin ifadeler eşitlik (32) ve (33)'de verilmiştir.

$$
\begin{array}{c|llll}
\multicolumn{1}{c}{} & \multicolumn{1}{c}{C_{1}} & C_{J} & \ldots & C_{n} \\
\cline { 2 - 6 } A_{1} & v_{11} & v_{1 j} & \ldots & v_{1 n} \\
A_{i} & v_{21} & v_{i j} & \ldots . & v_{i n} \\
\ldots & \ldots & \ldots & \ldots & \ldots \\
A_{m} & v_{m 1} & v_{m j} & \ldots & v_{m n} \\
\multicolumn{1}{c}{V_{i, j}=r_{i, j} \otimes w_{j}}
\end{array}
$$$$
\forall i=1,2, \ldots, m ; \text { ve } \forall i=1,2, \ldots, n \text {; }
$$

Dördüncü adımda ise her bir alternatif için pozitif ve negatif ideal çözüm değerleri bulunur. $\mathrm{Bu}$ değerlerden $\mathrm{A}^{+}$eşitlik (35)'te pozitif ideal çözümü, $\mathrm{A}^{-}$ise eşitlik (36)'da negatif ideal çözümü belirtmektedir. $\mathrm{Bu}$ ifadelere ait hesaplamalar aşağıdaki gibi verilmektedir.

$$
\begin{gathered}
A^{+}=\left(V_{1}^{+}, V_{j}^{+}, \ldots, V_{n}^{+}\right) \text {ve } V_{j}^{+}=\left\{\begin{array}{l}
(1,1,1) j \in B \\
(0,0,0) j \in C
\end{array}\right. \\
A^{-}=\left(V_{1}^{-}, V_{j}^{-}, \ldots, V_{n}^{-}\right) \text {ve } V_{j}^{-}=\left\{\begin{array}{l}
(0,0,0) j \in B \\
(1,1,1) j \in C
\end{array}\right.
\end{gathered}
$$

Beşinci adımda ise her bir kriterin pozitif ve negatif ideal çözüme uzaklık mesafeleri hesaplanmaktadır. Bulanık pozitif ideal çözüme olan uzaklık $d_{i+}$ ve bulanık negatif ideal çözüme olan uzaklık $\mathrm{d}_{\mathrm{i}-}$ olmak üzere aşağıdaki gibi gösterilmektedir. Mesafelerin hesaplanması sonucu artık bulanık olmayan gerçek sayılar elde edilmiş olur [5].

$$
\begin{gathered}
d_{i+} \sum_{j=1}^{n} d\left(v_{i j} ; v_{j}^{+}\right)= \\
\sum_{j=1}^{n} \sqrt{\frac{1}{3} *\left[\left(l_{i, j}-j_{j}^{+}\right)^{2}\right.}+ \\
\left(m_{i, j}-m_{j}^{+}\right)^{2}+ \\
\left.\left(u_{i, j}-u_{j}^{+}\right)^{2}\right] \quad d_{i-} \sum_{j=1}^{n} d\left(v_{i j} ; v_{j}^{-}\right)= \\
\sum_{j=1}^{n} \sqrt{\frac{1}{3} *\left[\left(l_{i, j}-j_{j}^{-}\right)^{2}\right.}+ \\
\left(m_{i, j}-m_{j}^{-}\right)^{2}+ \\
\left(u_{i, j}-u_{j}^{-}\right)^{2}
\end{gathered}
$$

Altıncı adımda ise $\mathrm{C}_{\mathrm{i}}$ yakınlık indeksini ifade etmek üzere, her bir kriter için yakınlık indeksi hesaplanır. Alternatiflerin sıralamasının elde edilebilmesi için beşinci adımda hesaplanan pozitif ve negatif ideal çözüme olan uzaklıklar kullanılarak $C_{i}$ yakınlık indeksleri bulunur. Her bir alternatifin yakınlık indeksi $\mathrm{i}=(1,2, \ldots, \mathrm{m})$ ve $\mathrm{C}_{\mathrm{i}} \in[0,1]$ olmak üzere (38) eşitliğindeki gibi hesaplanır.

$$
C_{i}=\frac{d_{i-}}{d_{i+}+d_{i-}}
$$

$\mathrm{C}_{\mathrm{i}}$ yakınlık indeksi 1' e yaklaştıkça ilgili alternatif için pozitif ideal çözüme yaklaştığını ve negatif ideal çözümden ise uzaklaştığını göstermektedir. Buradan yola çıılarak yakınlık indeks değerine göre alternatiflerin öncelik sıralaması yapılabilir. Yakınlık indeksi 1'e ne kadar yakınsa o alternatifin seçilme şansına o kadar artmaktadır.

\subsection{Uygulama}

Bu bölümde günümüzde gün geçtikçe daha da önem kazanan performans değerlendirmesinin banka sektöründeki bir uygulanmasını ele alınmaktadır. Çalışmada 2013-2018 yılları için Türkiye Bankalar Birliği'nden alınan raporlara göre aktif büyüklük sıralamasında ilk 8 bankanın Bulanık AHP ve Bulanık TOPSIS yöntemleri kullanılarak finansal performans değerlendirmesi yapılmaktadır. Çalışmanın ilk adımı olarak Bulanık AHP yöntemi ile bankaların finansal 
performanslarının değerlendirilmesinde etkili olan kriterlerin ağırlıkları hesaplanacaktır. İkinci olarak ise elde edilen bu ağırlıklar aracılığı ile öncelikle Bulanık TOPSIS yöntemiyle bankaların finansal performans değerlendirilmesi yapılacak olup ardından banka finansal performans değerlendirmesi, farklı bir yöntem olarak Bulanık AHP yöntemi ile de değerlendirilecektir. Şirketlerin finansal performanslarını belirlemek, ayrıca bu performans ve finansal oranlarla hisse senetlerinin borsa getirileri arasındaki ilişkiyi ölçen bir çalışma mevcuttur [21]. Ancak banka performans değerlendirmesi üzerinde hisse senedi getirisi arasında herhangi bir ilişki olmaması sebebi ile bu çalışma kapsamında bu kriter ele alınmamıştır $[22,23]$.

\subsubsection{Bulanık AHP ile Kriterlerin Ağırlıklarının Hesaplanması}

Çalışma kapsamında 3 farklı bankada çalışmakta olan ve daha önce farklı bankalarda görev yapmış olan 3 kişilik bir çalışma grubu oluşturulmuştur.

Banka performans değerlendirmelerinde ele alınacak ana ve alt kriterler belirlenirken hem literatür çalışmaları hem de bu çalışma kapsamında olușturulan çalıșma grubunda yer alan uzman kişilerin görüşleri dikkate alınmıștır. Çalışmada banka performans değerlendirmesine ilişkin ele alınan kriterlerin hiyerarşik yapısı Şekil 2.'de verilmektedir.

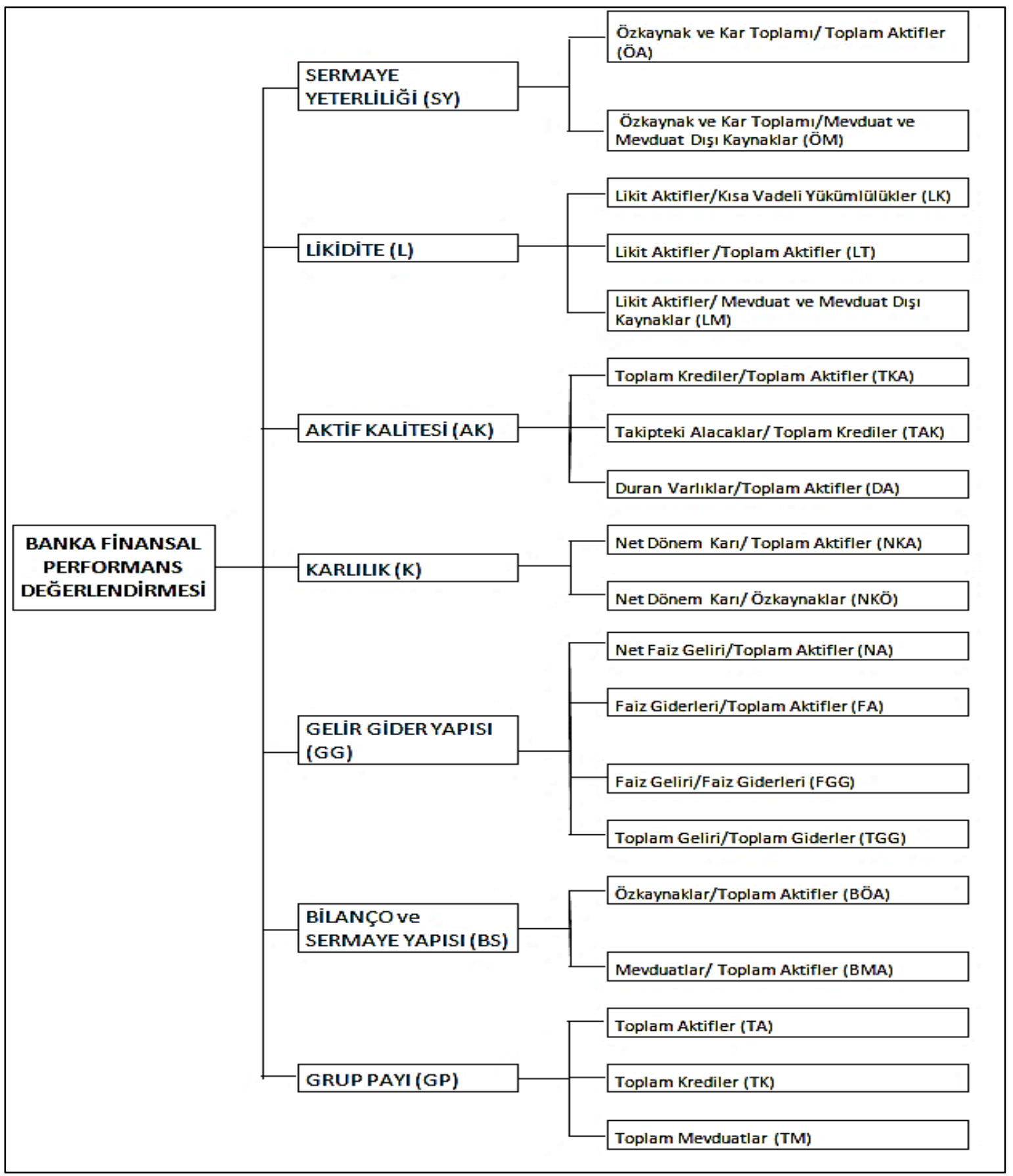

Şekil 2. Kriterlerin hiyerarşik yapısı 
Tablo 4. Sermaye yeterliliği alt kriterlerinin karșılaștırma matrisi

\begin{tabular}{ccc}
\hline Sermaye Yeterliliği (SY) & $\begin{array}{c}\text { Özkaynak ve Kar Toplamı / } \\
\text { Toplam Aktifler (ÖA) }\end{array}$ & $\begin{array}{c}\text { Özkaynak ve Kar Toplamı / Mevduat ve } \\
\text { Mevduat Dıșı Kaynaklar (ÖM) }\end{array}$ \\
\hline $\begin{array}{c}\text { Özkaynak ve Kar Toplamı / Toplam Aktifler } \\
\text { (ÖA) }\end{array}$ & $(1,1,1)$ & $(3 / 2,2,5 / 2)$ \\
$\begin{array}{c}\text { Özkaynak ve Kar Toplamı / Mevduat ve } \\
\text { Mevduat Dıșı Kaynaklar (ÖM) }\end{array}$ & $(2 / 5,1 / 2,2 / 3)$ & $(1,1,1)$ \\
\hline
\end{tabular}

Banka performans değerlendirmesine ilişkin ilgili ana kriter ve alt kriterlerin değerlendirilmesi için ilgili çalışma grubuna anket uygulanmış olup her bir kullanıcından bu kriterleri ikili olarak birbirleriyle karşılaștırılması istenmiștir. Yapılan literatür araştırmalarında kriterlerin ikili karşılaştırılmaları sırasında sayıların eşleniklerinin kullanılması sebebi ile Genişletilmiş Analiz Yönteminde aritmetik ortalamanın yeterli olmadığı konusunda görüşlerin olduğu görülmektedir bu sebeple anketlerde verilen cevapların birleştirilmesi için geometrik ortalama yöntemi kullanılmaktadır.

Çalışma kapsamında oluşturulan çalışma grubu üyeleri tarafından yapılan değerlendirmelerin geometrik ortalamaları sonucu oluşan ana kriterlerin karşılaştırılmasının yapıldığı matris ve alt kriterlerin karşılaştırıldığı matris örneklerine "Genişletilmiş Analiz Yönteminin Uygulanması" kısmında yer verilmektedir.

\subsubsection{Genişletilmiş Analiz Yönteminin Uygulanması}

Ana ve bu ana kriterlere bağlı alt kriterlerin ikili karşılaştırması yapılmasından sonra genişletilmiş analiz yöntemi ile kriterlerin ağırlıkları hesaplanmaktadır. $\mathrm{Bu}$ noktada ağırlıkların hesaplanmasındaki amaç alt kriterler için alt kriterlerin bağlı oldukları ana kriter üzerindeki etki derecesini belirleyebilmektir. Buna göre hangi alt kriter en fazla öneme sahip ve bağlı olduğu ana kriteri hangi oranda etkilediğini bulabilmektedir. Aynı mantıkla ana kriterler için yapılan karşılaştırmalarda da alternatiflerin seçiminde hangi ana kriterin etkisinin daha fazla olduğunu, her bir ana kriterin alternatiflerin seçiminde hangi oranda etkili olduğunu belirleyebilmektir.

Genişletilmiş Analiz Yöntemi uygulama adımlarında fazla sayıda hesaplama basamağı olması sebebi ile MS Excel formüllerinden yararlanılarak ilgili hesaplamalar yapılmıştır.

Alt kriter karşılaștırmalarına örnek olarak sermaye yeterliliği alt kriteri için Sermaye Yeterliliği (SY), Özkaynak ve Kar Toplamı / Toplam Aktifler (ÖA), Özkaynak ve Kar Toplamı / Mevduat ve Mevduat Dışı Kaynaklar (ÖM) olmak üzere hesaplamalar Tablo 4. de görüldüğü gibidir.

İlgili hesaplamalar sonucunda Tablo 5'te ağırlık değerleri bulunmaktadır.
Tablo 5. Sermaye yeterliliği ana kriterine ait alt kriterin ağırlıkları

\begin{tabular}{cc}
$\begin{array}{c}\text { Özkaynak ve Kar } \\
\text { Toplamı / Toplam } \\
\text { Aktifler (ÖA) }\end{array}$ & $\begin{array}{c}\text { Özkaynak ve Kar Toplamı / } \\
\text { Mevduat ve Mevduat Dışı } \\
\text { Kaynaklar (ÖM) }\end{array}$ \\
\hline 1 & 0
\end{tabular}

Tablo 6. Ana ve alt kriter ağırlıkları

\begin{tabular}{|c|c|c|c|}
\hline Ana Kriterler & Ağırlık & Alt Kriterler & Ağırlık \\
\hline \multirow{7}{*}{$\begin{array}{l}\text { Sermaye } \\
\text { Yeterliliği }\end{array}$} & \multirow{7}{*}{0,19} & Özkaynak ve Kar & \\
\hline & & Toplamı / Toplam & 0,19 \\
\hline & & Aktifler & \\
\hline & & Özkaynak ve Kar & \\
\hline & & Toplamı / Mevduat ve & 0 \\
\hline & & Mevduat Dıșı & 0 \\
\hline & & Kaynaklar & \\
\hline \multirow{7}{*}{ Likidite } & \multirow{7}{*}{0,21} & Likit Aktifler / Kısa & 0 \\
\hline & & Vadeli Yükümlülükler & 0 \\
\hline & & Likit Aktifler / Toplam & \\
\hline & & Aktifler & 0,2016 \\
\hline & & Likit Aktifler / Mevduat & חת \\
\hline & & ve Mevduat Dışı & 0,00798 \\
\hline & & & \\
\hline \multirow{4}{*}{ Aktif Kalitesi } & \multirow{4}{*}{0,02} & $\begin{array}{l}\text { Toplam Krediler / } \\
\text { Toplam Aktifler }\end{array}$ & 0,01 \\
\hline & & $\begin{array}{l}\text { Takipteki Alacaklar / } \\
\text { Toplam Krediler }\end{array}$ & 0 \\
\hline & & Duran Varlıklar / & 0.01 \\
\hline & & Toplam Aktifler & 0,01 \\
\hline \multirow{3}{*}{ Karlılık } & \multirow{3}{*}{0,19} & Net Dönem Karı / & 0 \\
\hline & & Toplam Aktifler & \\
\hline & & $\begin{array}{l}\text { Net Dönem Karı / } \\
\text { Özkaynaklar }\end{array}$ & 0,19 \\
\hline \multirow{7}{*}{$\begin{array}{l}\text { Gelir Gider } \\
\text { Yapısı }\end{array}$} & \multirow{7}{*}{0,27} & $\begin{array}{l}\text { Net Faiz Geliri /Toplam } \\
\text { Aktifler }\end{array}$ & 0 \\
\hline & & Faiz Giderleri / Toplam & 0 \\
\hline & & Aktifler & 0 \\
\hline & & Faiz Geliri / Faiz & 0.0675 \\
\hline & & Giderleri & 0,0675 \\
\hline & & Toplam Geliri / Toplam & 0,2025 \\
\hline & & Giderler & \\
\hline \multirow{3}{*}{$\begin{array}{c}\text { Bilanço ve } \\
\text { Sermaye Yapısı }\end{array}$} & \multirow{3}{*}{0,09} & Özkaynaklar / Toplam & 009 \\
\hline & & Aktifler & 0,09 \\
\hline & & $\begin{array}{l}\text { Mevduatlar / Toplam } \\
\text { Aktifler }\end{array}$ & 0 \\
\hline
\end{tabular}

"Sermaye Yeterliliği" ana kriterine bağlı alt kriter ağırlıklarını yorumlanacak olunursa "Özkaynak ve Kar Toplamı / Toplam Aktifler (ÖA)" alt kriterinin "Sermaye Yeterliliği" ana kriteri üzerinde önemli bir etkisi olduğu görülebilmektedir. Bunun yanında 
“Özkaynak ve Kar Toplamı / Mevduat ve Mevduat Dışı Kaynaklar (ÖM)" alt kriteri ise sıfır değerini almıştır. Diğer tüm alt kriterlere ait ikili karşılaştırma matrisleri de benzer şekilde hesaplanmaktadır.

İlgili ana kriterlere bağlı tüm alt kriterlerin ikili karşılaştırmaları sonrası ana kriterler de birbirleri ile karşılaştırılır. Ana kriterlerin ikili karşılaştırması sonrası elde edilen değerler Tablo 6'da verilmiştir.

Sermaye Yeterliliği (SY), Özkaynak ve Kar Toplamı / Toplam Aktifler (ÖA), Özkaynak ve Kar Toplamı / Mevduat ve Mevduat Dışı Kaynaklar (ÖM), Likidite ana kriteri (L) ve Likit Aktifler / Kısa Vadeli Yükümlülükler (LK), Likit Aktifler / Toplam Aktifler (LT), Likit Aktifler / Mevduat ve Mevduat Dişı Kaynaklar (LM), Aktif Kalitesi ana kriteri (AK) ve Toplam Krediler / Toplam Aktifler (TKA), Takipteki Alacaklar / Toplam Krediler (TAK), Duran Varlıklar / Toplam Aktifler (DA), Karlılık ana kriteri (K), Net Dönem Karı / Toplam Aktifler (NKA), Net Dönem Karı / Özkaynaklar (NKÖ), Gelir Gider Yapısı (GG), Net Faiz Geliri /Toplam Aktifler (NA), Faiz Giderleri / Toplam Aktifler (FA), Faiz Geliri / Faiz Giderleri (FGG), Toplam Geliri / Toplam Giderler (TGG), Bilanço ve Sermaye Yapısı ana kriteri (BS) ve Özkaynaklar / Toplam Aktifler (ÖA), Mevduatlar / Toplam Aktifler (BMA), Grup Payı ana kriteri (GP) ve Toplam Aktifler (TA), Toplam Krediler (TK), Toplam Mevduatlar (TM) olarak ifade edilecektir. Tüm ikili matris karşılaştırmaları sonrası ana kriter ağırlıkları ve bu ana kriterlere bağlı alt kriter ağırlıkları Tablo 6. da verilmektedir.

\subsection{Bulanık TOPSIS ile Banka Performans Değerlendirmesi}

İlgili çalışma grubu tarafından Bulanık AHP ile ana ve alt kriterlerin ağırlıklandırılması yapıldıktan sonra Bulanık TOPSIS yöntemi ile ele alınan sekiz banka için finansal performans değerlendirmesi yapılacaktır. Bankaların finansal performans değerlendirmesi için ilgili çalışma grubuna ikinci bir anket uygulanmış olup bu anket aracılığı ile çalışma grubu üyelerinin bankalar hakkındaki görüşleri toplanmıştır. Bu aşamada 7 adet ana kriterlere bağlı toplamda 19 adet alt kriterin bulunması ve ele alınacak 8 banka için çalışma grubu üyelerinin alt kriterler bazında çok detaylı bir değerlendirme yapmakta zorlanmaları sebebi ile yapılacak değerlendirmelerin verimli olmayacağı düşünülmüş olup, çalışma kapsamında ana kriterler temel alınarak çalışma grubu üyelerinden ana kriterlere göre değerlendirme yapmaları istenmiştir.

Banka performans değerlendirmesi yapılacak 8 bankanın ve performans karşılaştırması yapılırken ele alınacak ana kriterler ve problemin hiyerarşik yapısı Şekil 3'de verilmektedir.

Çalışmada 2013 - 2018 yılları için Türkiye Bankalar Birliği'nden alınan raporlara göre aktif büyüklük sıralamasında ilk 8 bankanın performans değerlendirilmesi ele alınacaktır. Ele alınan bankalar 5 yıl boyunca ilk 8 banka arasında kalmayı başarmış bankalardır. Bu bankalar aşağıdaki gibidir:

Türkiye Cumhuriyeti Ziraat Bankası (TZB)

- $\quad$ Türkiye İş Bankası A.Ş. (TİB)

- $\quad$ Türkiye Garanti Bankası A.Ş. (TGB)

- $\quad$ Akbank T.A.Ş. (ABK)

- $\quad$ Türkiye Halk Bankası A.Ş. (THB)

- $\quad$ Yapı ve Kredi Bankası A.Ş. (YKB)

- $\quad$ Türkiye Vakıflar Bankası T.A.O. (TVB)

- $\quad$ Finans Bank A.Ş. (FB)

Şekil 3'de ilk seviyede "Banka Finansal Performans Değerlendirme" bașlığı altında problemin amacı, ikinci seviyede değerlendirmede kullanılacak kriterler ve son eviyede ise genel hiyerarşi tanımlarında "alternatifler" olarak söz edilen ve bizim problemimizde ise performans değerlendirmesi yapılacak bankalar yer almaktadır.

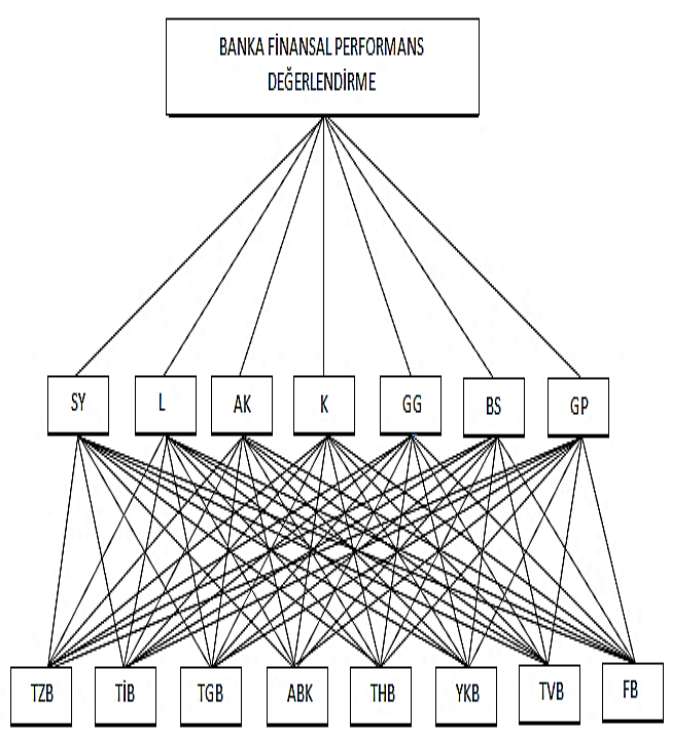

Şekil 3. Banka performans değerlendirme hiyerarşik yapısı

İlgili çalışma grubundaki kullanıcı değerlendirmelerini birleştirebilmek için yapılan değerlendirmelerin aritmetik ortalaması alınarak ilerlenmiştir. Uygulanan anketlerdeki değerlerin aritmetik ortalamaları ile bulanık karar matrisi elde edilmiş olup, elde edilen üçgensel bulanık sayı değerleri Tablo 7'de verilmektedir. Bulanık karar matris tablosuna normalizasyon işlemi uygulanarak Tablo 8 elde edilir.

Hesaplamanın üçüncü adımı, önceki bölümde Bulanık AHP ile hesaplanmış olan ana kriterlerin ağırlıkları kullanılarak hesaplamanın ikinci adımında belirlenmiş olan normalize karar matrisinin, ağırlıklandırılmış bulanık normalize karar matrisine dönüştürülmesidir. Bunu sağlayabilmek için normalize edilmiş karar matrisinde yer alan değerler, ilgili kriterin ağırlığı ile çarpılır. Böylece Tablo 9 da görülen ağırlıklandırılmış bulanık normalize karar matrisi elde edilmiş olunur. 
Tablo 7. Bulanık karar matrisi

\begin{tabular}{ccccccccc}
\hline & SY & L & AK & K & GG & BS & GP \\
\hline Tï & $(7,67 ; 9,33 ; 10)$ & $(5,67 ; 7,67 ; 9,33)$ & $(6,33 ; 8,33 ; 9,67)$ & $(7 ; 9 ; 10)$ & $(4,33 ; 6,33 ; 8,33)$ & $(5 ; 7 ; 8,67)$ & $(4,33 ; 6,33 ; 8,33)$ \\
TGB & $(6,33 ; 8 ; 9,33)$ & $(7 ; 8,67 ; 9,67)$ & $(7 ; 8,67 ; 9,67)$ & $(5,67 ; 7,67 ; 9,33)$ & $(5 ; 7 ; 8,67)$ & $(4,33 ; 6,33 ; 8)$ & $(5 ; 6,67 ; 8)$ \\
FB & $(3 ; 5 ; 7)$ & $(5,7,9)$ & $(3,67 ; 5,67 ; 7,33)$ & $(2,33 ; 4,33 ; 6,33)$ & $(4,33 ; 6,33 ; 8,33)$ & $(5,67 ; 7,67 ; 9)$ & $(3 ; 5 ; 7)$ \\
TZB & $(6,33 ; 8,33 ; 9,67)$ & $(9,10 ; 10)$ & $(6,33 ; 8,33 ; 9,67)$ & $(7 ; 9 ; 10)$ & $(4,33 ; 6,33 ; 8,33)$ & $(5,67 ; 7,67 ; 9,33)$ & $(7 ; 8,67 ; 9,67)$ \\
TVB & $(3,67 ; 5,67 ; 7,67)$ & $(4,33 ; 6,33 ; 8,33)$ & $(3,67 ; 5,67 ; 7,67)$ & $(3,67 ; 5,67 ; 7,67)$ & $(4,33 ; 6,33 ; 8)$ & $(3,67 ; 5,67 ; 7,67)$ & $(5 ; 6,67 ; 8)$ \\
YKB & $(3,67 ; 5,67 ; 7,33)$ & $(6,33 ; 8,33 ; 9,67)$ & $(3 ; 5 ; 7)$ & $(5,67 ; 7,67 ; 9,33)$ & $(2,67 ; 4,33 ; 6,33)$ & $(4,33 ; 6,33 ; 8)$ & $(6,33 ; 8,33 ; 9,67)$ \\
THB & $(3 ; 5 ; 7)$ & $(4,33 ; 6,33 ; 8)$ & $(4,33 ; 6,33 ; 8)$ & $(3,67 ; 5,67 ; 7,67)$ & $(5 ; 7 ; 9)$ & $(4,33 ; 6,33 ; 8,33)$ & $(3,67 ; 5,67 ; 7,67)$ \\
ABK & $(4,33 ; 6,33 ; 8,33)$ & $(3,33 ; 5 ; 6,67)$ & $(2,33 ; 4,33 ; 6,33)$ & $(5 ; 7 ; 8,67)$ & $(5 ; 7 ; 8,33)$ & $(3 ; 5 ; 7)$ & $(3,67 ; 5,67 ; 7,67)$ \\
\hline
\end{tabular}

Tablo 8. Normalize edilmiș karar matrisi

\begin{tabular}{|c|c|c|c|c|c|c|c|}
\hline & SY & $\mathrm{L}$ & $\mathrm{AK}$ & $\mathrm{K}$ & $\mathrm{GG}$ & BS & GP \\
\hline TїB & $\begin{array}{c}(0,767 ; 0,933 ; 1,0 \\
00)\end{array}$ & $\begin{array}{c}(0,567 ; 0,767 ; 0,9 \\
33)\end{array}$ & $\begin{array}{c}(0,655 ; 0,861 ; 1,0 \\
00)\end{array}$ & $\begin{array}{c}(0,700 ; 0,900 ; 1,0 \\
00)\end{array}$ & $\begin{array}{c}(0,481 ; 0,704 ; 0,9 \\
26)\end{array}$ & $\begin{array}{c}(0,536 ; 0,750 ; 0,9 \\
29)\end{array}$ & $\begin{array}{c}(0,448 ; 0,655 ; 0,8 \\
62)\end{array}$ \\
\hline TGB & $\begin{array}{c}(0,633 ; 0,800 ; 0,9 \\
33)\end{array}$ & $\begin{array}{c}(0,700 ; 0,867 ; 0,9 \\
67)\end{array}$ & $\begin{array}{c}(0,724 ; 0,897 ; 1,0 \\
00)\end{array}$ & $\begin{array}{c}(0,567 ; 0,767 ; 0,9 \\
33)\end{array}$ & $\begin{array}{c}(0,556 ; 0,778 ; 0,9 \\
63)\end{array}$ & $\begin{array}{c}(0,464 ; 0,679 ; 0,8 \\
57)\end{array}$ & $\begin{array}{c}(0,517 ; 0,689 ; 0,8 \\
27)\end{array}$ \\
\hline FB & $\begin{array}{c}(0,300 ; 0,500 ; 0,7 \\
00)\end{array}$ & $\begin{array}{c}(0,500 ; 0,700 ; 0,9 \\
00)\end{array}$ & $\begin{array}{c}(0,380 ; 0,586 ; 0,7 \\
58)\end{array}$ & $\begin{array}{c}(0,233 ; 0,433 ; 0,6 \\
33)\end{array}$ & $\begin{array}{c}(0,481 ; 0,704 ; 0,9 \\
26)\end{array}$ & $\begin{array}{c}(0,607 ; 0,822 ; 0,9 \\
65)\end{array}$ & $\begin{array}{c}(0,310 ; 0,517 ; 0,7 \\
24)\end{array}$ \\
\hline TZB & $\begin{array}{c}(0,633 ; 0,833 ; 0,9 \\
67)\end{array}$ & $\begin{array}{c}(0,900 ; 1,000 ; 1,0 \\
00)\end{array}$ & $\begin{array}{c}(0,655 ; 0,861 ; 1,0 \\
00)\end{array}$ & $\begin{array}{c}(0,700 ; 0,900 ; 1,0 \\
00)\end{array}$ & $\begin{array}{c}(0,481 ; 0,704 ; 0,9 \\
26)\end{array}$ & $\begin{array}{c}(0,607 ; 0,822 ; 1,0 \\
00)\end{array}$ & $\begin{array}{c}(0,724 ; 0,896 ; 1,0 \\
00)\end{array}$ \\
\hline TVB & $\begin{array}{c}(0,367 ; 0,567 ; 0,7 \\
67)\end{array}$ & $\begin{array}{c}(0,433 ; 0,633 ; 0,8 \\
33)\end{array}$ & $\begin{array}{c}(0,380 ; 0,586 ; 0,7 \\
93)\end{array}$ & $\begin{array}{c}(0,367 ; 0,567 ; 0,7 \\
67)\end{array}$ & $\begin{array}{c}(0,481 ; 0,704 ; 0,8 \\
89)\end{array}$ & $\begin{array}{c}(0,393 ; 0,607 ; 0,8 \\
22)\end{array}$ & $\begin{array}{c}(0,517 ; 0,689 ; 0,8 \\
27)\end{array}$ \\
\hline YKB & $\begin{array}{c}(0,367 ; 0,567 ; 0,7 \\
33)\end{array}$ & $\begin{array}{c}(0,633 ; 0,833 ; 0,9 \\
67)\end{array}$ & $\begin{array}{c}(0,310 ; 0,517 ; 0,7 \\
24)\end{array}$ & $\begin{array}{c}(0,567 ; 0,767 ; 0,9 \\
33)\end{array}$ & $\begin{array}{c}(0,296 ; 0,481 ; 0,7 \\
04)\end{array}$ & $\begin{array}{c}(0,464 ; 0,679 ; 0,8 \\
57)\end{array}$ & $\begin{array}{c}(0,655 ; 0,862 ; 1,0 \\
00)\end{array}$ \\
\hline THB & $\begin{array}{c}(0,300 ; 0,500 ; 0,7 \\
00)\end{array}$ & $\begin{array}{c}(0,433 ; 0,633 ; 0,8 \\
00)\end{array}$ & $\begin{array}{c}(0,448 ; 0,655 ; 0,8 \\
27)\end{array}$ & $\begin{array}{c}(0,367 ; 0,567 ; 0,7 \\
67)\end{array}$ & $\begin{array}{c}(0,556 ; 0,778 ; 1,0 \\
00)\end{array}$ & $\begin{array}{c}(0,464 ; 0,678 ; 0,8 \\
93)\end{array}$ & $\begin{array}{c}(0,379 ; 0,586 ; 0,7 \\
93)\end{array}$ \\
\hline ABK & $\begin{array}{c}(0,433 ; 0,633 ; 0,8 \\
33) \\
\end{array}$ & $\begin{array}{c}(0,333 ; 0,500 ; 0,6 \\
67)\end{array}$ & $\begin{array}{c}(0,241 ; 0,448 ; 0,6 \\
55) \\
\end{array}$ & $\begin{array}{c}(0,500 ; 0,700 ; 0,8 \\
67)\end{array}$ & $\begin{array}{c}(0,556 ; 0,778 ; 0,9 \\
26)\end{array}$ & $\begin{array}{c}(0,322 ; 0,536 ; 0,7 \\
50)\end{array}$ & $\begin{array}{c}(0,379 ; 0,586 ; 0,7 \\
93)\end{array}$ \\
\hline
\end{tabular}

Tablo 9. Ağırlıklandırılmıș bulanık normalize karar matrisi

\begin{tabular}{|c|c|c|c|c|c|c|c|}
\hline & SY $(0,19)$ & $L(0,21)$ & $\mathrm{AK}(0,02)$ & $\mathrm{K}(0,19)$ & GG $(0,27)$ & BS $(0,09)$ & GP $(0,03)$ \\
\hline \multirow{2}{*}{ TíB } & $(0,1457 ; 0,17$ & $(0,1191 ; 0,1611 ; 0$ & $(0,0131 ; 0,0172 ; 0$ & $(0,1330 ; 0,1710 ; 0$ & $(0,1300 ; 0,1900 ; 0$ & $(0,0482 ; 0,0675 ; 0$ & $(0,0134 ; 0,0196 ; 0$ \\
\hline & $73 ; 0,1900)$ & (1959, & (0200) & (1900) & ,2500) & ,0836) & (0259) \\
\hline \multirow{2}{*}{ TGB } & $(0,1203 ; 0,15$ & $(0,1270 ; 0,1821 ; 0$ & $(0,0145 ; 0,0179 ; 0$ & $(0,1077 ; 0,1457 ; 0$ & $(0,1500 ; 0,2100 ; 0$ & $(0,0418 ; 0,0611 ; 0$ & $(0,0155 ; 0,0207 ; 0$ \\
\hline & $02 ; 0,1773)$ & ,2031) & ,0200) & ,1773) & ,26 & 07 & 02 \\
\hline \multirow{2}{*}{ FB } & $(0,0570 ; 0,09$ & $(0,1050 ; 0,1470 ; 0$ & $(0,0076 ; 0,0117 ; 0$ & $(0,0443 ; 0,0823 ; 0$ & $(0,1300 ; 0,1900 ; 0$ & $(0,0547$ & $(0,0093 ;$ \\
\hline & $50 ; 0,1330)$ & (1890) & ,0152) & ,1203) & ,2500) & 08 & ,02 \\
\hline \multirow{2}{*}{ TZB } & $(0,1203 ; 0,15$ & $(0,1890 ; 0,2100 ; 0$ & $(0,0131 ; 0,0172 ; 0$ & $(0,1330 ; 0,1710 ; 0$ & $(0,1300$ & $(0,0547$ & $(0,0217 ; 0,0269 ; 0$ \\
\hline & $83 ; 0,1837)$ & ,2100) & ,0200) & (1900) & ,2500) & 0 & ,0300) \\
\hline \multirow{2}{*}{ TVB } & $(0,0697 ; 0,10$ & $(0,0909 ; 0,1329 ; 0$ & $(0,0076 ; 0,0117 ; 0$ & $(0,0697 ; 0,1077 ; 0$ & $(0,1300 ; 0,1900 ; 0$ & $(0,0354 ; 0,0547 ; 0$ & $(0,0155 ; 0,0207 ; 0$ \\
\hline & $77 ; 0,1457)$ & ,1749) & ,015 & 14 & ,24 & &, 02 \\
\hline \multirow{2}{*}{ YKB } & $(0,0697 ; 0,10$ & $(0,1329 ; 0,1749 ; 0$ & $(0,0062 ; 0,0103 ; 0$ & $(0,1077 ; 0,1457 ; 0$ & $(0,0800 ; 0,1300 ; 0$ & $(0,0418 ; 0,0611 ; 0$ & $(0,0196 ; 0,0259 ; 0$ \\
\hline & $77 ; 0,1393)$ & ,2031) & ,0145) & ,1773) & ,1900) & ,0772) & \\
\hline \multirow{2}{*}{ THB } & $(0,300 ; 0,500$ & $(0,433 ; 0,633 ; 0,8$ & $(0,448 ; 0,655 ; 0,8$ & $(0,367 ; 0,567 ; 0,7$ & $(0,556 ; 0,778 ; 1,0$ & $(0,464 ; 0,678 ; 0,8$ & $(0,379 ; 0,586 ; 0,7$ \\
\hline & $; 0,700)$ & 00) & 27) & 67) & 00) & 93) & 93) \\
\hline \multirow[b]{2}{*}{$\mathrm{ABK}$} & $(0,433 ; 0,633$ & $(0,333 ; 0,500 ; 0,6$ & $(0,241 ; 0,448 ; 0,6$ & $(0,500 ; 0,700 ; 0,8$ & $(0,556 ; 0,778 ; 0,9$ & $(0,322 ; 0,536 ; 0,7$ & $(0,379 ; 0,586 ; 0,7$ \\
\hline & $; 0,833)$ & 67) & 55) & 67) & 26) & $50)$ & 93) \\
\hline
\end{tabular}

Tablo 10. Yakınlık indeksi değer sıralaması

\begin{tabular}{ccc}
\hline Bankalar & Yakınlık İndeks Değerleri & Sıralama \\
\hline Türkiye Cumhuriyeti Ziraat Bankası A.Ş. (TZB) & 0,119726143 & 1 \\
Türkiye İş Bankası A.Ş. (TIB) & 0,114243684 & 2 \\
Türkiye Garanti Bankası A.Ș. (TGB) & 0,112383809 & 3 \\
Yapı ve Kredi Bankası A.Ş. (YKB) & 0,095031914 & 4 \\
Türkiye Halk Bankası A.Ş. (THB) & 0,09347523 & 5 \\
Akbank T.A.Ş. (ABK) & 0,093010427 & 6 \\
Türkiye Vakıflar Bankası T.A.O. (TVB) & 0,091575928 & 7 \\
Finans Bank A.Ș. (FB) & 0,090551721 & 8 \\
\hline
\end{tabular}

Hesaplamanın dördüncü adımı olarak $\mathrm{A}^{+}$pozitif ideal çözüm ve $\mathrm{A}^{-}$negatif ideal çözüm belirlenir. Hesaplamanın beşinci adımı olarak her bir kriterin pozitif ve negatif çözüme olan uzaklıkları (37) eşitliğindeki gibi hesaplanır. Pozitif ve negatif çözüme olan uzaklıklardan yararlanılarak elde edilen yakınlık indeks değerleri aşağıdaki gibidir. Tablo 10. daki veriler değerlendirilecek olunursa en yüksek yakınlık indeks değerine sahip olan Türkiye Cumhuriyeti Ziraat Bankası A.Ş. (TZB) diğer bankalara göre daha iyi bir performansa sahiptir. 
Tablo 11. Sermaye yeterliliği kriteri için alternatiflerin karșılaștırılması

\begin{tabular}{|c|c|c|c|c|c|c|c|c|}
\hline & TİB & TGB & FB & TZB & TVB & YKB & THB & $\mathrm{ABK}$ \\
\hline TїB & $(1 ; 1 ; 1)$ & $(1,14$ & $(2,36$ & $(1,1$ & $(2,11 ;$ & $(2,3$ & 5) & $\begin{array}{c}(2,11 ; 2,62 ; 3 \\
13)\end{array}$ \\
\hline TGB & $(0,47 ; 0,63$ & $(1 ; 1 ;$ & $(1,5$ & $(0,74$ & $(1,36 ; 1,8$ & $(1,78 ; 2$, & $2,8)$ & $\begin{array}{c}(1,36 ; 1,82 ; 2 \\
36)\end{array}$ \\
\hline FB & $(0,29 ;$ & $(0,39$ & $(1$ & $(0,3$ & $(0,5$ & $(0,78 ; 1$ & $\begin{array}{c}(0,74 ; 1 ; 1,3 \\
6)\end{array}$ & $\begin{array}{c}(0,87 ; 1,26 ; 1 \\
78)\end{array}$ \\
\hline TZB & $(0,47 ; 0,63$ & $(0,74 ; 1 ;$ & $(1,99 ; 2$ & $(1 ; 1 ; 1)$ & 8) & $(1,3$ & $\begin{array}{c}(2,11 ; 2,62 ; \\
3,13)\end{array}$ & $(1,5 ; 2 ; 2,5)$ \\
\hline TVB & $(0,32 ; 0,3$ & $(0,42 ; 0,5$ & $(0,87$ & 36 & $(1$ & 4) & $\begin{array}{c}(0,87 ; 1,26 ; \\
1,78)\end{array}$ & $\begin{array}{c}(0,56 ; 0,79 ; 1 \\
14)\end{array}$ \\
\hline YKB & $(0,54 ; 0,35$ & $(0,36 ; 0,44$ & $(0,78 ; 1$ & $(0,42 ; 0,55$ & $(0,87 ; 1,1$ & $(1 ; 1$ & $\begin{array}{c}(0,87 ; 1,14 ; \\
1,52)\end{array}$ & $(0,74 ; 1 ; 1,36)$ \\
\hline THB & $(0,28 ; 0$, & $36 \cdot 04$ & $(0,74 ; 1 ; 1,36)$ & 7) & $(0,56 ; 0,7$ & 6.08 & (1. & $\begin{array}{c}(0,47 ; 0,63 ; 0, \\
87)\end{array}$ \\
\hline ABK & $(0,32 ; 0,38 ; 0,47)$ & $(0,42 ; 0,55 ; 0,73)$ & $(0,56 ; 0,79 ; 0,87)$ & $(0,4 ; 0,5 ; 0,67)$ & $(0,87 ; 1,26 ; 2,78)$ & $(0,74 ; 1 ; 1,36)$ & $\begin{array}{c}(1,14 ; 1,59 ; \\
2,11)\end{array}$ & $(1 ; 1 ; 1)$ \\
\hline
\end{tabular}

\subsection{Bulanı AHP ile Banka Performans} Değerlendirmesi

Banka performans değerlendirmesi için ilgili çalışma grubu tarafından Bulanık AHP yöntemi ile kriter ağırlıkları daha önceki bölümlerde belirlenmişti. Kriter ağırlıklandırmalarının ardından ilgili kriter ağırlıklandırmasından faydalanılarak Bulanık TOPSIS ile banka performans sıralaması yapılmıştı. Çalışmanın bu kısmında ise daha önce belirlenen kriter ağırlıkları kullanılarak banka performans sıralaması Bulanık AHP yöntemi ile de ele alınacaktır. Böylece sonuçların tutarlığı farklı iki yöntem aracılığı ile değerlendirilmiştir. Bulanık AHP yöntemi ile uygulama adımlarında fazla sayıda hesaplama basamağı olması sebebi ile MS Excel formüllerinden yararlanılarak ilgili hesaplamalar yapılmıştır.

Bulanık AHP ile banka performans değerlendirmesi için kullanıcılardan her bir alternatifin ilgili kriter bazında değerlendirmesi istenmiştir. $\mathrm{Bu}$ amaçla yapılan anket sonuçları geometrik ortalama ile tek bir değere indirgenebilmesi sağlanmıştır. Çalışmada ele alınan ana kriterlerden "Sermaye Yeterliliği" kriteri için alternatiflerin karşılaştırılmasına ait yapılan değerlendirme sonuçları Tablo 11. de yer almaktadır. Tablo 11. de yer alan veriler kullanılarak her bir alternatif için sentez değerleri (3) ve (5) eşitlikleri ile hesaplanmaktadır. Elde edilen sentez değerleri her bir alternatif için karşılaştırılarak bulanık sentetik derece değerlerinin olabilirlik dereceleri Tablo 12 . deki gibi elde edilmektedir.

Tablo 12. de her satırda yer alan değerlerin minimum olan değeri alınarak sermaye yeterliliği kriteri için alternatiflerin öncelik değerleri bulunmaktadır.

$$
W^{\prime}=(1 ; 0,59 ; 0 ; 0,67 ; 0 ; 0 ; 0 ; 0,06)
$$

Öncelik değerlerinin elde edilmesi sonrası $W^{\prime}$ vektörü (39) eşitliğindeki gibi bulunmaktadır.
(40) eşitliğindeki sonuçlara göre sermaye yeterliliği kriteri altında en iyi performansa sahip ya da yatırımcılar için seçilebilecek en iyi alternatif "Türkiye İş Bankası (TİB)" iken bu alternatifi sırası ile "Türkiye Cumhuriyeti Ziraat Bankası A.Ş. (TZB)", "Türkiye Garanti Bankası A.Ş. (TGB)" ve "Akbank T.A.Ş (ABK)" takip etmektedir. Diğer alternatifler ise sıfır değerini almıştır.

Tablo 12. Sermaye yeterliliği bulanık sentetik derece olabilirlik değerleri

\begin{tabular}{ccccccccc}
\hline & TİB & TGB & FB & TZB & TVB & YKB & THB & ABK \\
\hline TİB & - & 1 & 1 & 1 & 1 & 1 & 1 & 1 \\
TGB & 0,59 & - & 1 & 0,93 & 1 & 1 & 1 & 1 \\
FB & 0 & 0,21 & - & 0,17 & 0,89 & 0,88 & 1 & 0,88 \\
TZB & 0,67 & 1 & 1 & - & 1 & 1 & 1 & 1 \\
TVB & 0 & 0,33 & 1 & 0,25 & - & 1 & 1 & 1 \\
YKB & 0 & 0,33 & 1 & 0,23 & 1 & - & 1 & 1 \\
THB & 0 & 0,09 & 0,86 & 0 & 0,75 & 0,71 & - & 0,71 \\
ABK & 0,06 & 0,43 & 1 & 0,38 & 1 & 1 & 1 & - \\
\hline
\end{tabular}

Normalizasyon işlemi sonrası elde edilen $W$ vektörü (40) eşitliğindeki gibidir.

$$
W=(0,43 ; 0,25 ; 0 ; 0,29 ; 0 ; 0 ; 0 ; 0,02)
$$

Alternatiflerin, çalışmada ele alınan 7 ana kriter altında değerlendirilmesi ile elde değerler daha önce elde edilen kriter ağırlıkları ile çarpılır. Kriter ağırlıkları ile çarpılması sonrası satır bazlı ağırlık değerleri toplanır ve ilgili alternatife ait ağırlık değeri bulunmuş olur. Bulunan ağırlıklı değerler alternatiflerin üstünlük ağırlıklarını ifade etmektedir. $\mathrm{Bu}$ değerlere bakılarak alternatifler arasında öncelik sıralaması yapılabilmektedir. İlgili alternatiflerin her bir kriterdeki öncelik değerleri, kriterlerin ağırlık değerleri ve bunların bir sonucu olarak alternatiflerin üstünlük ağırlıkları önem ağırlık matrisi altında Tablo 13. de yer verilmiștir. 
Tablo 13. Önem ağırlık matrisi

Sermaye Yeterliliği Likidite Aktif Kalitesi Karlılık Gelir Gider Bilanço Grup Payı

\begin{tabular}{ccccccccc}
\hline Kriter Ağırlıklarl & 0,19 & 0,21 & 0,02 & 0,19 & 0,27 & 0,09 & 0,03 & $\begin{array}{c}\text { Alternatiflerin } \\
\text { Üstünlük } \\
\text { Ağırlıklarl }\end{array}$ \\
\hline TíB & 0,43 & 0,04 & 0,21 & 0,2 & 0,25 & 0,25 & 0,17 & 0,2325 \\
TGB & 0,25 & 0,21 & 0,16 & 0,15 & 0,02 & 0,2 & 0,11 & 0,1533 \\
FB & 0 & 0 & 0 & 0 & 0 & 0,1 & 0,12 & 0,0162 \\
TZB & 0,29 & 0,57 & 0,26 & 0,22 & 0,72 & 0,31 & 0,23 & 0,4579 \\
TVB & 0 & 0 & 0,051 & 0,038 & 0 & 0,06 & 0,05 & 0,0166 \\
YKB & 0 & 0,17 & 0,16 & 0,16 & 0 & 0,19 & 0,14 & 0,0948 \\
THB & 0 & 0 & 0,14 & 0,135 & 0 & 0,17 & 0,12 & 0,0509 \\
ABK & 0,02 & 0 & 0,01 & 0,077 & 0 & 0,05 & 0,052 & 0,0262 \\
\hline
\end{tabular}

Tablo 13. de görüldüğü üzere alternatiflerin üstünlük ağırlıkları bulunmaktadır. Üstünlük ağırlıkları sıralanması ile alternatifler arasındaki sıralama elde edilmiş olunur. Tablo 14. de alternatiflerin sıralaması verilmektedir.

Tablo 14. Alternatiflerin siralanması

\begin{tabular}{cc}
\hline $\begin{array}{c}\text { Alternatiflerin } \\
\text { Ustünnlük Ağırlıkları }\end{array}$ & Banka Adı \\
\hline 0,4579 & Türkiye Cumhuriyeti Ziraat Bankası \\
0,2325 & A.Ş. (TZB) \\
0,1533 & Türkiye İş Bankası A.Ş. (TİB) \\
0,0948 & Türkiye Garanti Bankası A.Ş. (TGB) \\
0,0509 & Yapı ve Kredi Bankası A.Ş. (YKB) \\
0,0262 & Türkiye Halk Bankası A.Ş. (THB) \\
0,0166 & Akbank T.A.Ş. (ABK) \\
0,0162 & Türkiye Vakıflar Bankası T.A.O. \\
& (TVB) \\
& Finans Bank A.Ş. (FB) \\
\hline
\end{tabular}

\section{Bulgular}

Çalışmada Bulanık AHP ile banka performansı üzerinde etkili olan kriterler ağırlıklandırılarak yapılmıştr. Bu amaçla öncelikle Bulanık AHP yöntemi kullanılarak bankaların finansal performansları üzerinde etkisi olduğu düşünülen 7 ana kriter ve bu ana kriterlere bağlı toplamda 19 adet alt kriter ele alınmıștır. Bulanık TOPSIS ve Bulanık AHP olmak üzere iki farklı yöntem ile bankaların performans sıralaması alt kriterlere ait yorum yapmanın zor olması ve karar vericiler tarafından doğru değerlendirmenin yapılamayacağının düşünülmesi sebebiyle çalışmada ana kriterler ele alınarak ilerlenmiștir. Karar vericilerin görüşleri doğrultusunda yapılan değerlendirmeler Bulanık AHP ile değerlendirilmiş olup finansal performans üzerinde en büyük etkiye sahip kriterin gelir gider yapısı kriteri olduğu görülmektedir. Bu sonuca bakılarak bankaların gelir gider oranı yüksek olan bir bankanın finansal performansının yüksek olabileceği yorumu yapılabilmektedir. Bunun yanında bankaların gelir gider yapısında yaşanabilecek bir dalgalanmanın bankanın performansını büyük ölçüde etkileyebileceği yorumu da yapılabilmektedir. Gelir gider yapısı kriterini sırası ile likidite ve aynı ağırlığa sahip olan sermaye yapısı ve karlılık oranının takip

ettiği görülmektedir. Yapılan değerlendirmeler
sonucu en düşük ağırlığa sahip olması sebebi ile grup payı kriterinin bankaların finansal performansı üzerinde en az etkiye sahip olan kriter olduğu yorumu yapilabilmektedir.

Elde edilen sonuçlara göre performansını arttırmaya yönelik çalışma yapan bir bankanın öncelikli olarak gelir gider yapısında iyileşme sağlamaya çalışması bankanın, kısa zamanda performans iyileşme adımlarında daha büyük bir sıçrama elde etmesini sağlayabileceği yorumları da yapılabilmektedir. Çalışmada aynı zamanda ana kriterlere bağlı olan alt kriterlerin de finansal performans üzerindeki etki dereceleri ya da başka bir ifade ile önem ağırlıklarına da yer verilmiştir. Alt kriterler arasında finansal performans üzerinde en fazla etkisi olan kriterin "Toplam Geliri/Toplam Giderler" alt kriteri olduğu söylenebilmektedir.

Yapılan kriter ağırlıklandırması sonrası 2013-2018 yılları arasında aktif büyüklük sıralamasında ilk sekiz banka arasında kalmayı bașarmıș olan bankaların performans değerlendirmesi Bulanık TOPSIS yöntemi ve Bulanık AHP yöntemleri ile ele alınmıștır. Böylece her iki yöntem ile sonuçlar değerlendirilmiş olup sonuçların birbiri ile paralel olduğu görülmüştür. İlgili finansal oranlar dikkate alınarak çalışma grubundaki kişilerin değerlendirmeleri doğrultusunda performans değerlendirmesinde ilk sırada "Türkiye Cumhuriyeti Ziraat Bankası A.Ş. (TZB)" yer alarak son sırada ise "Finans Bank A.Ș. (FB)" yer almıștır. Böylece Bulanık TOPSIS ve Bulanık AHP yöntemleri ile çalışma grubunda yer alan değerlendiricilerin görüşleri ve yorumları doğrultusunda ilgili oranların banka finansal performansı üzerindeki etkisi ve bu sonuçlara göre bankaların performans sıralaması yapılmış olmaktadır.

\section{Tartışma ve Sonuç}

Çalışmada elde edilen sonuçların, bankaların performans sıralamasına katkısının yanında bankalara yatırım yapacak kişilere, banka seçimi yapabilmesi konusunda da fayda sağlamaktadır. Çalışma değerlendirildiğinde çalışma grubunda yer alan karar verici kişilerin öznel yargılarının ve de 
değerlendirilen finansal oranların öncelikli tercihlerinin performans siralamasını değiştirebileceği yorumu da yapılabilmektedir. Bulanık AHP yöntemi ile alternatiflerin karşılaştırılması sırasında ele alınan kritere göre bankaların öncelik sıralamasının değiştiği görülmektedir. Ele alınan bir kritere göre tercih edilebilirliği ya da performansı yüksek olan bir alternatifin başka bir kritere göre tercih edilebilirliğinin düștüğü gözlemlenmektedir. $\mathrm{Bu}$ çalışma, içerisinde bulundurduğu yöntemler, yaklaşımlar ve bakış açıları ile diğer sektörlerde de yapılabilecek performans değerlendirme çalışmaları için yol göstermektedir. $\mathrm{Bu}$ çalışmada finansal oranlara yer verilerek finansal performans değerlendirilmesi üzerine çalışılmış ve bu açıdan literatüre katkısı bulunmaktadır ve konusu itibari ile de literatürde benzerine rastlanılamamıștır. Müșteri memnuniyetinin hemen hemen her sektörde en önemli kriter olma yolunda ilerlemesi sebebi ile gelecek çalıșmalarda müșteri memnuniyeti de bir kriter olarak alınarak performans değerlendirmesi üzerine çalışmalar yapılabilir. Ayrıca müşteri memnuniyeti kriterinin yanında banka performansını etkileyen diğer finansal olmayan kriterlerde eklenerek Bulanık AHP ve Bulanık TOPSIS yöntemleri ya da farklı yöntemler uygulanarak banka performans değerlendirme üzerine çalışmalar yapılabilir. Bunun yanında banka performans değerlendirmesi için farklı değişkenler ele alınarak değişkenler arasındaki ilişkiler üzerine de farklı çalışmalar yapılabilir.

\section{Etik Beyanı}

Bu çalışmada, "Yükseköğretim Kurumları Bilimsel Araştırma ve Yayın Etiği Yönergesi" kapsamında uyulması gerekli tüm kurallara uyulduğunu, bahsi geçen yönergenin "Bilimsel Araştırma ve Yayın Etiğine Aykırı Eylemler" başlığı altında belirtilen eylemlerden hiçbirinin gerçekleștirilmediğini taahhüt ederiz.

\section{Kaynakça}

[1] Denizhan, B., Yalçıner A., Berber, Ş. 2017. Analitik Hiyerarşi Proses ve Bulanık Analitik Hiyerarşi Proses Yöntemleri Kullanılarak Yeşil Tedarikçi Seçimi Uygulaması. Nevşehir Bilim ve Teknoloji Dergisi, 6(1), 63-68.

[2] Yacan, İ. 2016. Eğitim Kalitesinin Belirlenmesinde Etkili Olan Faktörlerin Bulanık AHP ve Bulanık TOPSIS Yöntemi ile Değerlendirilmesi. Pamukkale Üniversitesi Sosyal Bilimleri Enstitüsü, Yüksek Lisans Tezi, Denizli, 90s.

[3] Sağır, H., Doğanalp. B. 2016. Bulanık Çok Kriterli Karar Verme Perspektifinden Türkiye İçin Enerji Kaynakları Değerlendirmesi. Kastamonu Üniversitesi İktisadi ve İdari Bilimler Fakültesi Dergisi, 11(1), 243-254.
[4] Çalışkan, E., Eren, T. 2016. Bankaların Performanslarının Cok Kriterli Karar Verme Yöntemiyle Değerlendirilmesi. Ordu Üniversitesi Bilgi Teknolojileri Dergisi, 6(2), 85-107.

[5] Doğan, M., Şişman, B. 2016. Türk Bankalarının Finansal Performanslarının Bulanık AHP ve Bulanık MOORA Yöntemleri ile Değerlendirilmesi. Yönetim ve Ekonomi Dergisi, 23(2), 353-371.

[6] Mandic, K., Delibasic, B., Knezevic S., Benkovic S. 2014. Analysis of the Financial Parameters of Serbian Banks Through the Application of the Fuzzy AHP and TOPSIS Methods. Economic Modelling, 43, 30-37.

[7] Doğan, M. 2015. Comparision of Financial Performance of Participation Banks in Turkey. Journal of Economics, Finance and Accounting, 2(4), 1-4.

[8] Anderson, D.R., Sweeney, D.J., Williams, T.A., Camm, J.D., Cochran, J.J., Fry, M.J., Ohlmann, J.W. 2013. Quantitative Methods for Business, 13. Baskl, Cengage Learning, USA, 909s.

[9] Timor, M. 2011. Analitik Hiyerarşi Prosesi, 1. Baskı, Türkmen Kitapevi, İstanbul, 304s.

[10] Çetişli, B. 2006. Öznitelik Seçiminde Dilsel Kuvvetli Sinir Bulanık Sınıflayıcı Kullanımı. Eskişehir Osmangazi Üniversitesi Mühendislik Mimarlık Fakültesi Dergisi, 19(2), 109-129.

[11] Vatansever, K., Uluköy, M. 2013. Kurumsal Kaynak Planlaması Sistemlerinin Bulanık AHP ve Bulanık MOORA Yöntemleriyle Seçimi: Üretim Sektöründe Bir Uygulama. Celal Bayar Üniversitesi Sosyal Bilimler Dergisi, 11(2), 274293.

[12] Erdem, M. 2012. Türkiye'de Kombine Taşımacılık İçin Liman Yerinin Bulanık AHP İle Seçimi. İstanbul Üniversitesi Fen Bilimleri Enstitüsü, Yüksek Lisans Tezi, 111s, İstanbul.

[13] Chang, D.Y. 1996. Applications of The Extent Analysis Method on Fuzzy AHP. European Journal of Operational Research, 95(3), 649-655.

[14] Çiçekli, U.G., Karaçizmeli, A. 2013. Bulanık Analitik Hiyerarşi Süreci ile Başarılı Öğrenci Seçimi. Ege Üniversitesi İktisadi ve İdari Bilimler Fakültesi Örneği. Ege Stratejik Araştırmalar Dergisi, 4(1), 71-94.

[15] Göksu, A., Güngör, İ. 2008. Bulanık Analitik Hiyerarşik Proses ve Üniversite Tercih Sıralamasında Uygulanması. Süleyman Demirel Üniversitesi İktisadi ve İdari Bilimler Fakültesi Dergisi, 13(3), 1-26.

[16] Hwang, C.L., Yoon, K. 1981. Multiple Attribute Decision Making: Methods and Application, Springer, New York, 225s. 
[17] Demireli, E. 2010. TOPSIS Çok Kriterli Karar Verme Sistemi: Türkiye'deki Kamu Bankaları Üzerine Bir Uygulama. Girişimcilik ve Kalkınma Dergisi, 5(1), 85-107.

[18] Ünal, Y. 2011. Bulanık Çok Kriterli Karar Verme Yöntemleri ve Bir Takım Oyunu İçin Oyuncu Seçimi Uygulaması. Selçuk Üniversitesi Fen Bilimleri Enstitüsü, Yüksek Lisans Tezi, 155s, Konya.

[19] Özçakar, N., Demir, H.H. 2011. Bulanık TOPSIS Yöntemi ile Tedarikçi Seçimi. İstanbul Üniversitesi İşletme İktisadı Enstitüsü Dergisi, 22(69), 28-33.

[20] Ayvalı, N. 2015. Banka Başarısızlıklarında Aktif Kalitesinin Değerlendirilmesi. T.C. Marmara Üniversitesi Bankacılık ve Sigortacılık Enstitüsü, Yüksek Lisans Tezi, İstanbul, 184s.
[21] Ozen, E., Yeşildağ E. 2015. TOPSIS Performans Değerleme Ölçüsü ve Finansal Oranlar ile Hisse Senedi Getiri İlişkisi. Journal of Economics, 2(4), 482-500.

[22] Ünal, S., Yüksel R. 2017. Finansal Performans ve Hisse Senedi Getirisi İlişkisi: Bist Sürdürülebilirlik Endeksindeki Bankalar Üzerine Bir İnceleme. Uluslararası Yönetim İktisat ve İşletme Dergisi, ICMEB17 Özel Sayısı, 264-270.

[23] Sakarya, Ș., Aytekin, S.2013. İMKB'de İșlem Gören Mevduat Bankalarının Performansları ile Hisse Senedi Getirileri Arasındaki İliş̧ini Ölçülmesi: PROMETHEE Cok Kriterli Karar Verme Yöntemiyle Bir Uygulama. Uluslararası Alanya İşletme Fakültesi Dergisi, 5(2), 99-109. 